\title{
Firm-Manager Matching and the Tradeoffs of CFO Accounting Expertise*
}

\author{
Darren Bernard \\ dbernard@1ondon.edu \\ London Business School \\ Weili Ge \\ geweili@uw.edu \\ University of Washington \\ Dawn Matsumoto \\ damatsu@uw.edu \\ University of Washington \\ Sara Toynbee \\ Sara.Toynbee@mccombs.utexas.edu \\ University of Texas at Austin
}

\begin{abstract}
We examine the tradeoffs of CFO accounting expertise and their role in firm-manager matching decisions. Although prior work examines the positive effects of accounting expertise on several financial reporting outcomes, there is little evidence on the tradeoffs this expertise entails, much less how firms compensate for these tradeoffs. We conjecture that acquiring accounting expertise requires costly tradeoffs in terms of acquiring other skills, including operational knowledge and strategic expertise. We find that these tradeoffs are reflected in firms' hiring decisions ex ante and affect several ex post employment decisions. Collectively, the results suggest accounting expertise is a carefully weighed attribute of CFO hires that shapes and is shaped by the composition of the top management team.
\end{abstract}

\footnotetext{
* We thank workshop participants at Boston College, Cornell University, Emory University, Erasmus University Rotterdam, Harvard Business School, Iowa State University, Louisiana State University, The Ohio State University and University of Colorado at Boulder, the Bauer Accounting Symposium at the University of Houston, as well as Terrence Blackburne, Lucile Faurel (discussant), Mei Feng, Zhejia Ling, Sarah McVay, and Joe Schroeder (discussant) for helpful comments on earlier drafts of this paper. Ge and Matsumoto thank the Moss Adams Professorship and the Gerhard Mueller Professorship, respectively, at the University of Washington for financial support.
} 


\section{Introduction}

In contrast to standard agency models, a growing body of evidence suggests that the characteristics of corporate executives matter for firm policies and outcomes (e.g., Bertrand and Schoar 2003; Ge et al. 2011; Hoitash et al. 2016). In this vein, the accounting literature provides evidence that hiring an accounting expert $\mathrm{CFO}$ can improve financial reporting outcomes (e.g., Li et al. 2010). However, there is relatively little evidence on other factors that might affect the decision to hire an accounting expert CFO. For example, while CFO accounting expertise can provide certain benefits to the firm, developing this expertise generally requires the manager to forego experiences that would build expertise in other areas that are often within the scope of the CFO's responsibilities, such as managing the investor relations function and overseeing business development activity. Thus, this expertise also plausibly entails tradeoffs that could weigh on the firm's hiring decisions not only for the CFO, but also for other executives.

We provide evidence on the tradeoffs of CFO accounting expertise by examining firms' CFO employment decisions and other decisions about the structure and composition of the top management team. The basis of our approach is that boards are cognizant of a manager's skill set and take potential tradeoffs into consideration when making employment decisions. While boards' assessments about managers' skill sets could be incorrect on occasion, such incorrect assessments are unlikely to be pervasive or persist over the longterm (Bertrand and Schoar 2003). Thus, if accounting expertise involves significant tradeoffs to firms, we expect these tradeoffs to affect a number of firm-manager matching decisions. For example, if accounting expert CFOs lack the expertise to perform more operational functions, hiring an accounting expert CFO could influence other employment decisions at the firm (e.g., the composition of the top management team). Therefore, we use analyses of 
ex ante matching between the firm and the manager as well as several ex post tests to triangulate evidence.

Our analysis is based on a sample of over 8,000 CFO hiring events at U.S. public firms with employment hire dates between January 1, 2000 and December 31, 2013 as reported on BoardEx. We proxy for a CFO's accounting expertise by identifying those CFOs with a CPA designation (hereafter "CPA CFOs") on the basis that this proxy is easy to identify in a large sample and is an objective measure of accounting expertise. Although the definition likely excludes some accounting expert CFOs who do not hold a CPA license, it is unlikely to include CFOs who are not accounting experts, because the education and experience requirements necessary to become a CPA are extensive.

We begin by providing evidence that CPA CFOs trade off educational and career experiences to develop accounting expertise. The CFO role is multi-faceted and has evolved to include many operational, strategic, and general management responsibilities, so experiences that prepare the manager for these responsibilities are likely to be valuable. We find that, relative to non-CPA CFOs, CPA CFOs 1) are less likely to have a MBA, 2) are less likely to have prior finance experience, 3) have fewer years of their employment history working in a U.S. public company, and 4) are less likely to sit on the board of a public company. These findings suggest that acquiring accounting expertise requires a tradeoff in terms of acquiring other skills and knowledge that are plausibly valuable for CFOs of public companies.

To provide evidence on the significance of the tradeoffs to accounting expertise, we first model the firm's decision to hire a CPA CFO. Following the literature on fit/refit theory (e.g., Chen and Hambrick 2012), we assume that boards attempt to match their firms' needs with the appropriate CFO. Thus, we expect that firms with greater demand for accounting expertise will be more likely to hire an accounting expert CFO. In contrast, to the extent that 
accounting expert CFOs lack expertise in other areas and boards recognize this tradeoff, firms with greater demand for non-accounting expertise in the CFO position (e.g., business development or investor relations expertise) will be less likely to hire an accounting expert CFO. If manager characteristics do not matter to firm outcomes or the tradeoffs in their backgrounds are not perceived to be significant, we would observe no relation between the relative demand for accounting and non-accounting expertise and the expertise of the managers hired. Similarly, if the executive labor market is sufficiently illiquid to prevent efficient matching between firms and managers, we also would not observe any relation between firm needs and manager characteristics. ${ }^{1}$

Consistent with the systematic matching of firm and manager characteristics, we find that CPA CFOs are more likely to be hired at firms for which we posit that the relative demand for accounting expertise is higher. Specifically, firms are more likely to hire a CPA $\mathrm{CFO}$ when accounting in the industry is more complex and accounting regulatory requirements are more demanding. However, we expect that CPA CFOs are less effective at developing and implementing firm strategies, managing communications with the capital markets (i.e., investor relations), and managing complex operations. These functions are increasingly under the purview of the $\mathrm{CFO}$ but likely require different skill sets than those the average CPA CFO might possess. Consistent with this, we find that firms are less likely to hire a CPA CFO when they compete more on product differentiation, have more geographic segments, are in financial distress, make greater investments in capital and research and development, or when analyst following is higher.

We also examine how the composition of the firm's existing top management team influences firm-manager matching. If the tradeoffs of CFO accounting expertise are non-

\footnotetext{
${ }^{1}$ Furthermore, if we are unable to effectively capture a firm's demand for accounting and non-accounting expertise, we should observe no relation between firm characteristics and the type of CFO hired. We explore this possibility further in robustness tests discussed in Section 4.6.
} 
trivial, then the presence of other executives on the top management team with potentially complementary skills and job responsibilities could affect the firm's CFO hiring decision. We find that firms with a top manager holding an accounting related job title are less likely to hire a CPA CFO. Similarly, we find that firms with a Chief Operating Officer (COO) are more likely to hire a CPA CFO. To the extent a COO position reduces the breadth of a CFO's job responsibilities, the tradeoffs associated with hiring a CPA CFO are less pronounced for firms with existing COO positions.

The tradeoffs inherent in accounting expertise are also likely to affect subsequent employment decisions at the firm. First, as firms change over time, the relative importance of the tradeoffs of CFO accounting expertise should also change. Thus, a CFO's tenure with the firm depends on the evolution of the firm's product market, regulatory environment, financial characteristics, management team, and other factors. Factors that shift the firm toward demanding greater financial reporting skills improve the fit of accounting expert CFOs, whereas factors that shift the firm toward demanding greater operational, strategic, or general management expertise reduce the fit of accounting expert CFOs. Because there are transaction costs associated with replacing a manager, firms are unlikely to replace their CFO unless the decline in fit is sufficiently large that the benefits of replacement (in terms of fit) exceed the costs of replacement. Thus, we examine whether significant declines in firmmanager fit are associated with CFO turnover-i.e., whether firm-manager mismatching is associated with CFO turnover. To proxy for firm-manager fit, we use our model of the determinants of hiring a CPA CFO (hereafter "hiring model") to generate predicted values of the CPA variable for every year between the year of hire and each subsequent year of the CFO's tenure. Large negative (positive) changes in predicted values of CPA correspond to a substantially worse fit if the hired CFO was a CPA (non-CPA). We find evidence that significant declines in firm-CFO fit are associated with CFO turnover. 
Second, changes in the expertise of the CFO could lead the firm to adjust the composition of the top management team. While our prior analysis finds that the composition of the top management team at the time of the hiring decision influences whether a firm hires an accounting expert $\mathrm{CFO}$, it is also possible that firms change their organizational structure ex post to compensate for any major tradeoffs they make when hiring a CFO. Consistent with this, we analyze how changes in accounting expertise in the CFO position are associated with changes in the presence of an accounting related position or a $\mathrm{COO}$ position following a CFO appointment. We find evidence that firms establish other top management positions to compensate for deficiencies in CFOs' skill sets. For instance, we find that after an increase in CFO accounting expertise, the top management team is significantly more likely to drop a top accounting related position than add such a position.

Third, an important consideration for firms when hiring a CFO is whether the manager possesses the option value to eventually progress to the CEO position. Prior research provides evidence that there are distinct advantages to hiring a CEO internally (Shen and Canella 2002). Because CFOs are included in the set of possible internal hires, hiring a CFO with the requisite skill sets needed in the CEO position plausibly benefits the firm (Zhang and Rajagopalan 2003). CPA CFOs are less likely to possess these requisite skills because the CEO position requires greater non-accounting related expertise and less accounting related expertise. Thus, CPA CFOs could have lower option value to progress to the CEO position, which would represent an important tradeoff of CFO accounting expertise. Consistent with this idea, we find that CPA CFOs are less likely to be promoted to the CEO position in the five years following their CFO appointment relative to non-CPA CFOs.

Our study provides several important insights. While prior papers examine several firm outcomes associated with CFO accounting expertise (Aier et al. 2005; Li et al. 2010; Hoitash et al. 2016), there is relatively little evidence on the significance of the tradeoffs 
associated with this expertise for firms' CFO hiring decisions or other critical employment decisions. In contrast to prior work, we take the perspective that boards typically recognize tradeoffs inherent in hiring an accounting expert CFO and match firms' needs to the appropriate CFO. Consistent with this perspective, we find that accounting expert CFOs are more likely to match to firms with greater demand for accounting expertise but less likely to match to firms with greater demand for operational expertise or general management experience. ${ }^{2} \mathrm{We}$ also find that the structure of the top management team (namely, the presence of high-level accounting or operational positions) affects these CFO hiring decisions. The tradeoffs of CFO accounting expertise appear to affect firms' subsequent employment decisions as well. Changes in firms' needs - and therefore, firm-manager fit - are an important factor in subsequent turnover decisions. Further, we find evidence that the expertise of the $\mathrm{CFO}$ affects subsequent organizational structure decisions, including $\mathrm{CEO}$ hiring decisions and decisions about other high-level positions.

Collectively, the evidence suggests that accounting expertise is a carefully weighed attribute of the top management team. Boards appear to be aware of the tradeoffs associated with accounting expertise and make a number of organizational design decisions to avoid significant negative firm outcomes that might arise from a poor firm-manager fit. These findings are informative to boards and managers and speak to the broader literature that associates manager characteristics with high-level firm outcomes. In particular, our evidence suggests that identifying the effects of specific manager characteristics on firm outcomes is potentially complicated by firms' actions to mitigate the tradeoffs of those characteristics.

\footnotetext{
${ }^{2}$ These results may help to explain CFO hiring trends over time. As discussed further below, we observe a general decline in CPAs being hired as CFOs since the mid-2000s - a period of time that has seen the role of the CFO expand to include more general management and operational responsibilities. We also observe that firms in financial distress are less likely to hire CPA CFOs, which is consistent with the decline in the hiring of CPA CFOs during the financial crisis.
} 


\section{Motivation and empirical predictions}

In addition to their responsibility over traditional financial reporting and treasury functions, CFOs also increasingly oversee a variety of other firm activities (Favaro 2001; Groysberg et al. 2011; Consero 2013). For example, although setting the strategic vision of the organization is largely the purview of the CEO, the CFO is expected to provide insight and analysis to support the CEO's strategic planning. ${ }^{3}$ This analysis might involve guiding merger and acquisition (M\&A) decisions, developing business partnerships or alliances, and evaluating potential expansion plans. CFOs are also involved in communications with external stakeholders, playing a prominent role in building and maintaining relationships with the investment community and media (Favaro 2001). ${ }^{4}$ Further, CFOs are increasingly given more general management responsibilities, such as oversight over the information technology (IT), property, and logistic functions of the organization (Ernst \& Young 2010). It is plausible that CFOs with different skill sets have differing levels of success in managing these extensive responsibilities.

Consistent with the existence of benefits to accounting expertise, several prior studies find that accounting expert CFOs more effectively manage the accounting related responsibilities of their position, such as monitoring financial reporting and internal control functions (e.g., Aier et al. 2005; Li et al. 2010). For example, Li et al. (2010) show that firms are more likely to hire a $\mathrm{CFO}$ with accounting expertise after disclosing ineffective internal controls, and such hiring increases the likelihood of remediating internal control deficiencies. In addition, DeFond et al. (2005) find that the stock market reacts positively to hiring an

\footnotetext{
${ }^{3}$ For example, in a recent survey of Fortune 1000 CFOs, $81 \%$ indicated that their companies viewed the finance function as a "strategic business partner" (Consero 2013). In another survey of CFOs, 75\% indicated that they spend $50 \%$ or more of their time on strategic aspects of their role (Ernst \& Young 2010).

${ }^{4}$ The role of CFOs in investor relations is apparent given their prominent role in corporate conference calls - $\mathrm{Li}$ et al. (2014) find that comments by the CFO make up 33\% of the text spoken in their sample of conference calls (relative to the $47 \%$ of text spoken by the CEO). In addition, based on a 2012 survey of 736 investor relations executives, the National Investor Relations Institute (NIRI) reports that $65 \%$ of investor relations managers report to the $\mathrm{CFO}$ at their company.
} 
accounting expert to an audit committee but not to hiring a non-accounting financial expert, suggesting that accounting expertise is value-enhancing in certain circumstances.

We expect that investments made to develop accounting expertise lead managers to tradeoff educational and work experience in roles that build expertise important to executing non-accounting functions of the CFO. Prior research provides some evidence consistent with this tradeoff. For example, in their sample of CFOs, Ge et al. (2011) report a negative correlation between having a CPA and having an MBA. Having a more general educational background (such as an MBA) or work experience as the head of a business unit or geographic segment could provide the $\mathrm{CFO}$ with the familiarity and expertise necessary to help manage operational responsibilities (e.g., product sourcing). Similarly, backgrounds in investment banking, equity research, or asset management can be valuable to a firm because serving investor constituencies requires extensive knowledge of them-the information they demand and the incentives they face. Likewise, the need to contribute to strategic plans requires expertise that can accrue from positions in corporate business development, $\mathrm{M} \& \mathrm{~A}$ structuring at investment banks, or private equity. ${ }^{5}$ The investments necessary to acquire accounting expertise plausibly come at the expense of these experiences.

We expect the tradeoffs inherent in developing accounting expertise affect CFO hiring decisions and several ex post employment decisions at the firm. However, the significance of these tradeoffs is ultimately an empirical question. Even if accounting expert CFOs lack experience in operational capacities, investment banking, etc., they are likely to be supported by staff who do have many of these non-accounting experiences. Further, an accounting expert CFO likely develops skills important to managing non-accounting functions while working in accounting positions - for example, the ability to manage staff

\footnotetext{
${ }^{5}$ Brochet and Welch (2011) find that CFOs with "transaction experience" (e.g., experience in investment banking, private equity, venture capital, and management consulting) report goodwill that is more value-relevant, consistent with this type of experience resulting in higher quality valuations in an acquisition.
} 
and client relationships as a partner at a public accounting firm. These factors could, at least in part, mitigate the costs to the firm of hiring an accounting expert CFO.

Our main hypothesis, in alternative form, is as follows:

H1: Accounting expertise entails trading off other forms of expertise that firms consider valuable in the CFO position.

We develop four specific predictions based on this hypothesis. If managers' skill sets are important to fulfill the range of CFO job responsibilities, then a key function of boards is to "match" the needs of the firm with the appropriate CFO. This matching of managerial skills with the needs of the firm is the focus of the literature on fit/refit theory (e.g., Finkelstein et al. 2009; Chen and Hambrick 2012). For example, Chen and Hambrick (2012) argue that the extent to which a new CEO benefits a firm depends upon the degree to which she fits the firm's situation relative to the previous CEO. However, certain frictions can undermine efficient firm-manager matching. For example, it is possible that the executive labor market is relatively illiquid, which would restrict efficient matching between firms and managers. If such constraints are sufficiently binding, then systematic matching between firms and managers may not occur. Similarly, systematic matching may not occur if there is substantial uncertainty about firm needs or potential managers' abilities.

If efficient matching does occur, at least on average, a firm's hiring decision should reflect tradeoffs associated with the manager's skill set. In particular, the probability of hiring an accounting expert CFO should be increasing in the firm's demand for accounting expertise and decreasing in the firm's demand for non-accounting expertise. For example, firms that operate in industries with higher levels of accounting complexity should be more likely to hire accounting expert CFOs, whereas firms that have greater demand for strategic expertise (e.g., those that make more acquisitions) should be less likely to hire accounting expert CFOs. Thus, we put forth the following prediction with respect to firms' hiring decisions: 
P1: Firms are more (less) likely to hire accounting expert CFOs when there is greater demand for accounting (non-accounting) expertise in the CFO position.

We expect boards match the needs of the firm with the appropriate CFO at the time of hire. However, as the needs of the firm change over time, the expertise of the existing CFO may become a poor fit. For example, a non-accounting expert CFO may be considered a poor fit subsequent to the discovery of material weaknesses in internal controls. Just as we expect boards hire a CFO that matches the needs of the firm, we also expect boards recognize when the CFO does not meet the firm's changing needs and replace the CFO when the costs of doing so are lower than the costs associated with a poor firm-manager fit. Thus, to complement our prediction of the ex ante matching of firms and managers, we also examine whether changes in the demand for accounting and non-accounting expertise influence ex post $\mathrm{CFO}$ employment decisions (i.e., turnover). In particular, we expect that $\mathrm{CFO}$ turnover is more likely to occur when the characteristics of the firm change such that the relative demand for accounting and non-accounting expertise is significantly different from the time of the initial CFO appointment. Thus, our next prediction relates to the likelihood of CFO turnover:

P2: The likelihood of CFO turnover is higher when there is a significant decline in the firmmanager fit since the initial appointment.

Firm-level decisions are a joint effort by the top management team (Hambrick and Mason 1984), and boards can compensate for weaknesses in the skill sets of CFOs by shifting job responsibilities to other members of the top management team. If CFO accounting expertise entails trading off other expertise, it is plausible that CFO hiring decisions would also affect ex post hiring decisions of other executives. In other words, the tradeoffs in CFO accounting expertise could influence the composition of the top management team.

To explore this possibility, we consider the implications of changes in CFO accounting expertise for boards' subsequent decisions to establish senior accounting or operational positions. We expect changes in $\mathrm{CFO}$ accounting expertise to be associated with changes in 
the structure of the top management team. For instance, after hiring a non-accounting expert CFO to replace an accounting expert CFO, the board can hire a Chief Accounting Officer to compensate for the loss in CFO accounting expertise. Similarly, if the newly hired CFO is an accounting expert while the departing CFO does not have accounting expertise, the board can hire a $\mathrm{COO}$ to compensate for the lack of operational expertise. Thus, we state the following prediction regarding the composition of the top management team:

P3a: Increases (decreases) in CFO accounting expertise are associated with the addition (deletion) of a $\mathrm{COO}$ position in the top management team.

P3b: Increases (decreases) in CFO accounting expertise are associated with the deletion (addition) of an accounting related position in the top management team.

Another important factor boards are likely to consider when hiring a CFO is the manager's option value to advance to the CEO position. There are distinct benefits to promoting an internal candidate to the CEO position, as internal candidates have a deeper understanding of firms' internal operations and are generally easier for boards to evaluate than external candidates. ${ }^{6}$ Indeed, prior research shows that appointing an external CEO is associated with lower future firm operating performance (Shen and Cannella 2002), suggesting higher costs to appointing an external CEO relative to an internal CEO.

Prior research also shows that the likelihood of appointing an internal candidate to the CEO position is increasing in the supply of internal candidates (Zhang and Rajagopalan 2003). We expect that because the CEO position requires more non-accounting related expertise, accounting expert CFOs are less likely to possess the skill sets to be CEO. As a result, hiring an accounting expert CFO reduces the pool of internal candidates from which to choose the new CEO. Therefore, we next examine whether accounting expertise reduces the

\footnotetext{
${ }^{6}$ The board often appoints an "heir apparent" so the heir can develop the skills and knowledge necessary to be an effective CEO and the board can assess the heir's development before the CEO's departure (Zhang and Rajagopalan 2003).
} 
option value associated with a CFO appointment. Specifically, we state the following prediction with respect to the likelihood of CFO promotion to the CEO position:

P4: The likelihood of promotion from the CFO position to the CEO position is lower for accounting expert CFOs relative to non-accounting expert CFOs.

Collectively, our predictions examine whether the tradeoffs of accounting expertise are substantial enough to influence both the ex ante matching of firms and CFOs and ex post employment decisions at the firm. Findings consistent with these predictions (P1-P4) would lend support to our main hypothesis (H1).

\section{Data and sample selection}

Our primary source of information on CFOs is BoardEx, an international data provider that uses public disclosures to track executives' educational and employment backgrounds. We use the BoardEx employment file to select a sample of CFO hires at publicly traded U.S. companies with employment hire dates between January 1, 2000 and December $31,2013 .^{7}$ We identify CFOs by searching for job titles that include the term "CFO" or "Chief Financial Officer" but do not include the terms "Division", "Region", "CoCFO", "Deputy CFO”, or "CEO.” We also remove firm-years in which the firm has multiple $\mathrm{CFO}$ hires in the same year. Finally, we require that each executive in the sample remains employed by the company in the CFO position for a full fiscal year after the hire date (hereafter the "year after hire"). We impose these restrictions to ensure the sample consists of corporate-level CFOs who were neither subordinate to other executives in the finance function nor serving on an interim basis.

\footnotetext{
${ }^{7}$ For approximately $24 \%$ of our sample, BoardEx specifies the date of hire at a month-year or year level, not at the daily level. For these observations, we assume that the executive was hired at the end of the period for which the hire date is defined. For example, if BoardEx lists the hire date as October 2003, we assume a hire date of October 31, 2003, and if the hire date is listed as 2003, we assume that the hire date is December 31, 2003.
} 
As discussed previously, we proxy for accounting expertise by identifying CFOs with a CPA designation (CPA CFOs). ${ }^{8}$ Prior literature has also used experience at public accounting firms to capture accounting expertise (e.g., Li et al. 2010). We choose to measure accounting expertise using the CPA designation to ensure we do not miss accounting-based experience at non-Big 4 firms as well as to avoid classifying managers with experience in non-accounting related functions at the Big 4 firms (e.g., consulting) as having accounting expertise. In addition, given the heterogeneous nature of job titles and responsibilities across organizations, identifying accounting expertise based on prior work experience is likely to introduce more noise into our proxy.

Table 1, Panel A summarizes the sample selection procedure. In addition to the sample selection criteria discussed above, we require observations to have data on total assets in Compustat (in the year after hire). Our selection criteria yield a final sample of 8,497 CFO hire observations. ${ }^{9}$ Due to limited availability of data for control variables and certain dependent variables, however, the number of observations is generally lower in our tests. ${ }^{10}$

In Panel B of Table 1, we present an overview of our sample composition over the sample period. Our sample consists of an average of 606 CFO hires per year. On average, 49.6 percent of CFOs hold a CPA. The proportion of these newly hired CFOs holding a CPA increased gradually from 42.7 percent to 54.8 percent from 2000 until 2006, after which the proportion of CFOs hired with a CPA declined to 46.9 percent in 2013 (see also Figure 2).

\footnotetext{
${ }^{8}$ Although specific licensing requirements vary by state, most states require a four-year bachelor degree in business or accounting and 150 credit hours, passing the four-part Uniform CPA Exam, and at least one year of relevant work experience supervised by a verified CPA or equivalent.

${ }^{9}$ We use hiring event data rather than firm-manager-year panel data because the firm's needs are unlikely to remain constant over the entire length of the manager's tenure with the firm. Assuming there is some adjustment cost associated with executive turnover, turnover initiated by the firm would only occur once the cost of a poor fit is greater than the adjustment cost. Thus, a hiring model should reflect closer matching of firm and manager than a panel model. In Section 4.3, we explore the possibility that a poor fit leads to executive turnover.

${ }^{10}$ Specifically, in addition to financial data from Compustat, the calculation of some variables requires returns data from CRSP, M\&A deal information from Thomson SDC Platinum, analyst coverage from I/B/E/S, internal control and restatement data from Audit Analytics, compensation data from Execucomp, and other executive related information from BoardEx. We discuss measurement of these variables further in Section 4.
} 


\section{Empirical Results}

\subsection{CFO characteristics and background}

Table 2 presents descriptive statistics of CFO characteristics for our sample of CFO hires and the variables used in our main tests, which we define in Appendix A. We present these statistics for the full sample (Panel A) and then separately for CPA CFO hires and nonCPA CFO hires (Panel B). Of the CFOs in our sample, 38\% have an MBA degree $(M B A)$, $10 \%$ have finance backgrounds $(F I N)$, defined as experience in an investment bank or holding a CFA designation, and 34\% have prior experience as a CFO at a U.S. public company (PriorCFO). ${ }^{11}$ In addition, the average proportion of the CFO's prior years of experience (as listed on BoardEx) at a U.S. public company is 34\% (Prop Public US Exp); $16 \%$ of the CFOs held a board seat of a public company at the hire date (Board Seat at Hire Date); and approximately 60\% were hired externally (ExtHire). The average age (Age) of CFOs in our sample is 48 , and for CFOs that turnover during our sample period, the average tenure (Tenure) is 4 years.

We provide evidence of potentially important tradeoffs in the backgrounds and skill sets of CFOs in Panel B of Table 2 and Table 3. Panel B of Table 2 shows that, as expected, CPA CFOs are significantly less likely to have an MBA degree or prior finance experience (p-value $<0.01$ ). For example, $47 \%$ of non-CPA CFOs hold an MBA degree versus only $29 \%$ for CPA CFOs. The proportion of the CFO's prior years of experience (as listed on BoardEx) that was spent at a U.S. public company is significantly less for CPA CFOs than non-CPA CFOs. We also find that CPA CFOs are less likely to hold a board seat at a public

\footnotetext{
${ }^{11}$ We determine whether a CFO has experience in investment banking based on whether the CFO has been employed by an investment bank using a list compiled with data from Thomson SDC Platinum. Specifically, for each year from 1962 (the earliest year of data availability on SDC) through 2008, we obtain the names of the top 50 investment banks ranked by mergers and acquisitions, debt issuance, or equity issuance fees. We then match by hand the investment bank names obtained from this step to those listed in the BoardEx employment file to capture all variations of the investment bank names (including subsidiary names) listed in BoardEx. The final list includes 2,165 separate investment bank names.
} 
company than non-CPA CFOs at the time of hire (p-value $<0.01$ ), consistent with the notion that CPA CFOs often lack the general operational and management expertise that is desirable for a board position. In contrast, Table 3 shows that CFOs with an MBA degree typically have more general management and finance experience, as illustrated by the significantly positive correlations between MBA and finance experience, prior U.S. public company, and board experience. Overall, the evidence suggests that although CPA CFOs are likely to possess greater financial reporting expertise, this expertise is typically at the expense of finance and general operational and managerial experience. ${ }^{12}$

\subsection{Determinants of hiring a $C P A C F O(P 1)$}

We test our first prediction (P1) by examining the determinants of hiring a CPA CFO using the following logistic regression model where $C P A$ is equal to one if the newly hired $\mathrm{CFO}$ has received a CPA (or international equivalent) and zero otherwise:

$$
\begin{aligned}
& \operatorname{Pr}(C P A=1)=\gamma_{0}+\gamma_{1} \text { SOX }_{t}+\gamma_{2} \text { IndComplexity }_{t-3, t-1}+\gamma_{3} \mid \text { Accruals }_{t-1} \mid+ \\
& \gamma_{4} \text { ICW }_{t-1}+\gamma_{5} \text { MA }_{t-1}+\gamma_{6} \text { IndMA }_{t-1}+\gamma_{7} \text { GrossMargin }_{t-1}+ \\
& \gamma_{8} \text { IndGrossMargin }_{t-1}+\gamma_{9} \text { GeoSe }_{t-1}+\gamma_{10} \text { Distress }_{t-1}+ \\
& \gamma_{11} \text { Investment }_{t-1}+\gamma_{12} \text { AnalystFollow }_{t-1}+\gamma_{13} \text { Acct }_{t-1}+\gamma_{14} \text { CEOCPA }_{t-1}+ \\
& \gamma_{15} \text { COO }_{t-1}+\gamma_{16} \text { ROA }_{t-1}+\gamma_{17} \text { BM }_{t-1}+\gamma_{18} \text { Lev }_{t-1}+\gamma_{19} \operatorname{Ln}(M V E)_{t-1}+\varepsilon
\end{aligned}
$$

Equation (1) includes four variables that capture time-series and cross-sectional variation in the demand for accounting expertise at the firm- and industry-level. Appendix A provides exact variable definitions. We expect that the incentive to hire a CPA CFO is stronger during the initial adoption years of the Sarbanes-Oxley Act (SOX), as firms were required to comply with the new internal control disclosure requirements under Section 404 that became effective in 2004. To examine this effect, we include an indicator variable equal to one for

\footnotetext{
${ }^{12}$ Table 3 also reveals expected associations between other executive characteristics and background variables. For instance, CFO age is positively correlated with prior CFO experience, the likelihood of holding a board seat at a public company at the time of hire, and being an external hire at the sample firm.
} 
CFO hires that occurred between 2004 and 2006, and zero otherwise (SOX). ${ }^{13}$ We measure industry-level accounting complexity using the average number of restatements unrelated to fraud in the firm's industry group in the three years prior to the CFO hire year (IndComplexity). ${ }^{14}$ Industries with complex accounting practices are likely to experience more restatements on average (Peterson 2012). We use the absolute level of accruals scaled by total assets $(\mid$ Accruals $\mid)$ as a firm-specific measure of accounting complexity, as accruals often require substantial judgment and estimation by managers. Finally, we include a measure of internal control quality using an indicator variable for whether the firm disclosed an internal control weakness in the fiscal year prior to the hire year $(I C W)$. We expect that the probability of hiring a CPA CFO is increasing in these four variables (i.e., $\gamma_{1}$ through $\gamma_{4}>0$ ).

We include eight variables to proxy for demand for non-accounting expertise. To capture the firm's demand for high-quality strategic decision-making, we use M\&A activity and gross margin, a measure of product differentiation. Mergers and acquisitions are an important mechanism through which firms implement their strategic direction (e.g., Hoberg and Phillips 2010). We take the natural log of one plus the number of acquisitions a firm makes in the year prior to the CFO's hire date to capture M\&A activity $(M A)$. We also include the variable IndMA, calculated as the natural log of one plus the total number of acquisitions of an industry in the year prior to the CFO's hire date, to capture any demand for strategic decision-making arising from M\&A activity at the industry-level (e.g., due to M\&A waves). Greater reliance on product differentiation requires greater strategy-related expertise in developing business partnerships and creating effective marketing strategies. We use a firm's gross margin in the year prior to the CFO's hire year to proxy for the firm's strategy type (e.g., cost leader versus product differentiator) (GrossMargin). These strategies likely

${ }^{13}$ Results are robust to alternative definitions for the time period of the SOX variable - specifically, 2003-2006 and 2003-2007.

${ }^{14}$ We use three-digit SIC codes to define industry groups when calculating industry-level independent variables. Results are robust to using two-digit SIC groups or Fama-French 12 industry classifications. 
vary significantly across industries; thus we also include the industry median gross margin (IndGrossMargin).

We use analyst following (AnalystFollow) to proxy for a firm's demand for investor relations expertise. Firms with higher analyst following likely invest greater resources in managing communications with the capital markets, and thus likely require a CFO with greater expertise in investor relations. Additionally, we use three measures to capture firms' demand for general management experience: number of geographic segments (GeoSeg), likelihood of financial distress (Distress), and total investment (Investment). General business experience is likely necessary to effectively manage functions such as IT and logistics across geographically dispersed operations. Similarly, firms that are in financial distress likely require general management experience to navigate the significant business changes that are required to turn around a company. ${ }^{15} \mathrm{We}$ also consider the overall level of investment in capital expenditures and research and development, as these investment decisions require strategic and operational evaluation prior to implementation. These variables are all increasing in the demand for non-accounting expertise, so we expect their coefficients to be negative (i.e., $\gamma_{5}$ through $\gamma_{12}<0$ ).

We also examine whether a firm's CFO hiring decision is a function of several characteristics of the top management team. Many job responsibilities of the CFO likely overlap with those of other top-level executives. It is plausible then that the composition of the top management team can affect the decision of who to hire (i.e., which managerial skill sets are important in the hiring decision). First, we examine the possibility that the presence of a high-level accounting position such as Chief Accounting Officer makes it less likely that the CFO has to be actively involved in the accounting functions at the firm. We include two

\footnotetext{
${ }^{15}$ Consistent with this conjecture, Custodio et al. (2013) find that firms in financial distress pay more for "generalist" CEOs, suggesting that general management experience is more desirable when firms are in financial distress.
} 
variables to capture the level of accounting expertise at the firm at the time of the CFO's hire: Acctg, which equals one if BoardEx indicates the employment of an individual with a job description including the words "Accounting" or "Controller" (e.g., Chief Accounting Officer, Principal Accounting Officer) at the firm as of the hire date of the CFO, and zero otherwise; and CEOCPA, which equals one if the CEO as of the CFO's hire date has a CPA and zero otherwise. Second, we examine whether the presence of a COO influences the decision to hire a $\mathrm{CPA} \mathrm{CFO} ; \mathrm{COO}$ is an indicator variable equal to one if the firm has a $\mathrm{COO}$ (or equivalent) at the time of hire. We expect that when a firm has a COO to manage nonaccounting responsibilities, the scope of the CFO's responsibilities is likely to be more focused on financial reporting and related activities; therefore, firms with COOs will be more likely to hire CFOs with accounting expertise, all else equal.

Finally, we include several variables to control for firm characteristics that potentially influence the hiring decision: return on assets $(R O A)$ to control for performance, book-tomarket ratio $(B M)$ to control for growth prospects, leverage (Lev) to control for financial structure, and the natural log of market value of equity $(\operatorname{Ln}(M V E))$ to control for firm size. An overview of the timing of variable measurement is illustrated in Figure 1 and descriptive statistics of our determinants variables are reported in Table $2 .^{16}$

Panel A of Table 4 provides the coefficient estimates of several variants of Equation (1). Panel B presents the average marginal effects. Columns (1) and (2) present results for specifications including only the variables that capture firms' demand for accounting and non-accounting expertise, respectively. We combine these specifications in Column (3) and add the three variables related to the compensating effects of other top management team

\footnotetext{
${ }^{16}$ We do not control for the CPA status of the prior CFO, as doing so could control away the predicted effects if firm and industry characteristics are stable over time. Similarly, we do not control for characteristics of the CFO (e.g., MBA status) because our thesis is that acquiring accounting expertise comes at the cost of developing more general, non-accounting expertise. Thus, controlling for elements of this tradeoff would plausibly control away the effects we predict.
} 
members' backgrounds in Column (4). Finally, we present the results of our full specification, including the controls for firm characteristics, in Column (5).

Column (1) shows that all the coefficients on the variables that capture firms' demand for accounting expertise are significantly positive, with the exception of the coefficient on $\mid$ Accruals $\mid .{ }^{17}$ Column (2) shows that the coefficients on five of the eight variables that capture firms' demand for non-accounting expertise in the CFO position are significantly negative. Firms are less likely to hire CPA CFOs when there is greater demand for strategy expertise (GrossMargin), investor relation activities (AnalystFollow), and general management experience (GeoSeg, Distress, Investment). The results remain similar in Column (3) and Column (4). Once we include controls for other firm characteristics in Column (5), the coefficient on IndGrossMargin becomes significantly negative; however, the coefficients on ICW and AnalystFollow become insignificant. The latter result is likely due to the high correlation between analyst following and firm size; firms with large market capitalization generally have a greater need to cultivate relationships with Wall Street. ${ }^{18}$ Overall, the results in Table 4 are consistent with P1; firms are significantly more likely to hire CPA CFOs when the demand for accounting expertise in the executive team is high and less likely to hire CPA CFOs when other, non-accounting related expertise is more important. ${ }^{19}$

\footnotetext{
${ }^{17}$ While the coefficient on $\mid$ Accruals $\mid$ is not significant, further investigation reveals that there are some observations with extreme values of $\mid$ Accruals $\mid$ even after winsorizing the variable at the $1 \%$ and $99 \%$ level. These extreme observations are generally correlated with extreme negative operating performance (e.g., large restructuring charges). When we separately control for these extreme observations, the coefficient on $\mid$ Accruals $\mid$ is significantly positive, consistent with firms with more complex accounting hiring CPA CFOs.

${ }^{18}$ In particular, when we exclude firm size from the model in Column (5), the coefficient on AnalystFollow is significantly negative with a t-statistic of -4.76 ( $p$-value $<0.01)$.

${ }^{19}$ We interpret firms' hiring outcomes as a reflection of their demand for specific CFO expertise; however, it is possible that managers select into firms with particular characteristics. To the extent these preferences for certain types of firms are related to the manager's skill set-i.e., they chose to work for firms at which they expect to perform best - our interpretation of the results would continue to hold. However, if managers' preferences are unrelated to their skill set and are correlated with our variables of interest, we could be attributing our results to the matching of firms' needs with managers' skills when, in fact, it is due to some unidentified managerial preference. One such potential preference might stem from risk aversion (e.g., Hoitash et al. 2016). For example, if CPA CFOs are generally more risk averse than non CPA CFOs, they might have stronger preferences to avoid working for distressed firms. Thus, the fact that distressed firms are less likely to hire CPA CFOs might be due to CPA CFOs' preferences rather than the firm's demand for general management
} 
The coefficients on the variables related to the management team are also broadly consistent with our expectations. We find that the presence of an accounting-focused position on the management team lowers the probability of hiring a CPA CFO and that the existence of a COO position increases the probability of hiring a CPA CFO. Interestingly, however, the presence of a CEO with a CPA increases the probability of hiring a CPA CFO. Although this result is contrary to the notion that firms hire accounting expert CFOs when they lack this expertise in their top management team, to the extent the CEO plays a role in hiring the CFO, the positive association is consistent with social psychology research that suggests biases toward demographically similar individuals (Westphal and Zajac 1995). It is also possible that the existence of a CPA CEO captures other, less observable reasons accounting expertise is important on the top management team. Finally, we find that larger firms and firms with fewer growth opportunities (i.e., higher book-to-market ratio) are significantly less likely to hire CPA CFOs.

The average marginal effects reported in Panel B of Table 4 suggest the findings are economically significant. For example, firms are $3.3 \%$ more likely to hire a CPA CFO during the initial SOX implementation years and $14.8 \%$ less likely to hire a CPA CFO when they are in financial distress (Column (5)). These effects are considerable given that the average likelihood of hiring a CPA CFO is $49.6 \%$. To gauge the joint significance of the variables measuring the demand for non-accounting expertise, we calculate the difference between the probability of hiring a CPA when these variables are high versus low. High (low) corresponds to the 75 th (25th) percentiles of the distributions for continuous variables and 1

experience. However, we note that risk aversion could provide only a partial alternative interpretation of our results given that many of the firm characteristics associated with hiring a CPA CFO have little apparent relation to firm risk. Moreover, we examine whether CPA CFOs, relative to non CPA CFOs, have a larger proportion of their total compensation that is fixed (under the assumption that risk averse managers would demand greater fixed compensation). We find no evidence that this is the case. While we cannot definitively rule out the possibility that managerial preferences (unrelated to managers skill sets) influences our results, we do not find strong evidence that risk aversion, in particular, is driving our results nor can we think of another obvious managerial preference that would differ systematically between CPA CFOs and non CPA CFOs. 
(0) for indicator variables. We keep the variables measuring the demand for accounting expertise, the firm controls, and the CEOCPA, COO, and Acctg variables at their mean values. The difference in these probabilities is approximately $23 \%$ (for the specification in Column (5) of Table 4). We calculate the joint significance of the variables measuring the demand for accounting expertise using a similar procedure and find a difference in the probability of hiring a CPA when these variables are high versus low of $13 \% .^{20}$

Taken together, the results suggest that CPA CFOs are valued for their accounting expertise and companies respond to demand for financial reporting expertise by hiring CPAs as CFOs. However, the tradeoffs associated with developing accounting expertise also appear to be significant enough to influence firms' hiring decisions; firms tend to appoint non-CPA CFOs if there is a greater demand for operational or general management skills. Boards also appear to consider complementarities in the management team when they make hiring decisions.

\subsection{CFO turnover (P2)}

To the extent that our hiring model is reasonably descriptive of the firm-manager matching process, we expect a higher probability of CFO turnover when the factors that explain the firm-manager match change significantly. Thus, to examine P2, we use our hiring model to identify situations where there has been a significant decline in the fit of the CFO at the firm since the initial appointment. Specifically, we first calculate the predicted probability of hiring a CPA CFO using Equation (1) for the year of hire and each subsequent firm-year until the CFO's departure (PredCPA $A_{t+n}$, where $t$ is the hire year). We then calculate

\footnotetext{
${ }^{20}$ These percentages are similar for the specification in Column (4) of Table 4 (i.e., excluding the control variables). The differences in probabilities, however, are somewhat lower if variables that are statistically insignificant in Column (5) of Table 4 are instead held at their mean values (specifically, $21 \%$ and $8 \%$ for the variables measuring non-accounting expertise and accounting expertise, respectively). Also, because this calculation is based on differences in the probability of hiring a CPA when all the proxies for a type of demand are high versus low, the combined effect is predicted for hypothetical firms. Nonetheless, these percentages highlight the joint economic significance of our determinants variables.
} 
$\triangle C P A_{-} F i t_{t+n}$, which equals the predicted value in each year subsequent to the date of hire less the predicted value at the hire date $\left(\triangle C P A_{-} F i t_{t+n}=\operatorname{Pred}_{C P A_{t+n}}-\operatorname{PredCP} A_{t}\right)$. Higher (lower) values represent situations where the needs of the firm change toward (away from) needing a CPA CFO. Put differently, if the firm has a non-CPA CFO, a high value of $\triangle C P A{ }_{-} i_{t+n}$ would suggest a decline in fit, whereas, if the firm has a CPA CFO, a low value of $\triangle C P A_{-}$Fit $_{t^{+} n}$ would suggest a decline in fit. Thus, we define a PoorFit $t_{t+n}$ indicator variable equal to one if the firm has a CPA CFO (non-CPA CFO) and $\triangle C P A A_{-} i_{t+n}$ is in the bottom (top) quintile of the distribution. We then estimate the probability the CFO leaves the firm in a given year (CFO_Exit $\left.t_{t+n+1}\right)$ using the following logistic regression: ${ }^{21}$

$$
\begin{aligned}
& \operatorname{Pr}\left(\text { CFO_Exit }_{t+n+1}=1\right)=\gamma_{0}+\gamma_{1} \text { PoorFit }_{t+n}+\gamma_{2} \text { Ret }_{t+n}+\gamma_{3} \text { BoardSeat }_{t}+ \\
& \quad \gamma_{4} \text { CEOTenure }_{t}+\gamma_{5} \text { Ag }_{t+n}+\gamma_{6} \text { PriorCFO }_{t}+\gamma_{7} \operatorname{Ln}\left(\text { MVE }_{t+n}\right)+\gamma_{8} \text { Lev }_{t+n}+ \\
& \quad \gamma_{9} \text { BM }_{t+n}+\gamma_{10} \text { ROA }_{t+n}+\phi_{j}+\psi_{n}+e_{t+n+1}
\end{aligned}
$$

We include a number of control variables that are likely to affect the propensity of a CFO exit, including lagged returns, $\mathrm{CEO}$ tenure, $\mathrm{CFO}$ age, and measures of a CFO's ability (prior CFO experience and board experience) (Mian 2001). Further, we include CFO tenure fixed effects to control for the propensity for CFOs to turnover at similar points in their tenure as well as industry fixed effects. We estimate Equation (2) separately for non-CPA CFOs and CPA CFOs because the effects of the controls on turnover are plausibly different between CPA and non-CPA CFOs.

Results of this analysis are presented in Table 5. Columns (1) and (2) report results for the non-CPA CFO and CPA CFO subsample, respectively. We find a positive coefficient on the PoorFit $t_{+n}$ indicator variable in Column (1), suggesting that non-CPA CFOs are more likely to leave the firm when the firm's demand for accounting expertise increases (consistent with P2). We find similar evidence in Column (2) for the sample of CPA CFOs, indicating

\footnotetext{
${ }^{21}$ Ideally, we would capture only CFO departures that are involuntary in the sense that they are due to a mismatch between the CFO's skills and the needs of the firm. However, identifying the true underlying reasons for CFO departures is empirically difficult; very few CFOs are explicitly fired (e.g., Mian 2001).
} 
that CPA CFOs are more likely to leave the firm when the firm's demand for non-accounting expertise increases. We continue to find significant positive coefficients on the PoorFit $t_{t+n}$ indicator when we control for the full set of determinants as shown in Columns (3) and (4). Overall, these results suggest that CFOs are more likely to turnover when their skill sets become a worse fit for their firm's current needs. ${ }^{22}$

\subsection{Compensating changes in the top management team (P3)}

In this section, we examine the association between changes in $\mathrm{CFO}$ accounting expertise and subsequent changes in the presence of $\mathrm{COO}$ and accounting related positions at the firm (P3a and P3b). We classify CFO appointments as either $A d d C P A$, when the $\mathrm{CFO}$ hired has a CPA and the prior CFO did not, or DropCPA, when the CFO hired does not have a CPA and the prior CFO did. Thus, for this analysis we eliminate appointments where the prior and current $\mathrm{CFO}$ had similar accounting expertise (both CPAs or both non-CPAs) as well as hiring events for which we do not have data on the identity of the prior CFO. We also remove firms that either have or do not have $\mathrm{COO}$ positions both before and after hiring the $\mathrm{CFO}$ (i.e., firms without changes in the presence of the $\mathrm{COO}$ position). We then define observations as DropCOO (AddCOO) where the firm had (did not have) a $\mathrm{COO}$ in the year prior to the CFO's hire, but does not have (has) a COO by the end of the second calendar year after the CFO's hire. This approach assumes that boards would restructure the top management team within two years to adapt to any changes in the skill sets of their CFOs. We use similar definitions for AddAcctg and DropAcctg and similar sample construction for the analysis of the presence of accounting related positions.

Table 6, Panel A presents a contingency table of the proportion of CFO hires that (1) represent the addition (deletion) of a CPA CFO and (2) occur in conjunction with the addition

\footnotetext{
${ }^{22}$ We do not examine the accounting expertise of the CFOs hired as replacements to the CFOs in this turnover analysis, because the replacement CFOs are included in the primary sample for our hiring model (Section 4.2). Thus, examining whether firms whose characteristics now suggest the need for a CPA CFO (non-CPA CFO) subsequently hire such a CFO would be redundant.
} 
(deletion) of a COO. The results indicate that when a firm moves from a CPA CFO to a nonCPA CFO (DropCPA row), it is more likely to drop its COO position (51.6\%) versus add a COO position (48.4\%). In contrast, when a firm moves from a non-CPA CFO to a CPA CFO ( $A d d C P A$ row), it is more likely to add a COO position (53.8\%) versus drop its COO position (46.2\%). A Chi-square test indicates a significant association between the decision to hire an accounting expert CFO and subsequent changes to the COO position $\left(\chi^{2}=3.071, \mathrm{p}<0.10\right)$.

Table 6, Panel B presents the contingency table for accounting related positions. Consistent with the results for $\mathrm{COO}$ positions, we find that when a firm moves from a CPA CFO to a non-CPA CFO (DropCPA row), it is more likely to add another accounting related position to the management team $(51.4 \%)$ rather than drop such a position $(48.6 \%)$. The reverse is true when a firm moves from a non-CPA CFO to a CPA CFO (AddCPA row): the firm is significantly more likely to drop an accounting related position $(59.8 \%)$ rather than add such a position $(40.2 \%)\left(\chi^{2}=10.617, \mathrm{p}<0.01\right)$. Overall, these results are consistent with $\mathrm{P} 3$, reinforcing the idea that firms recognize the tradeoffs in CFO accounting expertise and take actions to adapt to changes in the skill sets of CFOs.

\subsection{Progression to the CEO position (P4)}

Our final prediction examines whether hiring a CPA CFO is costly to a firm because it reduces the pool of internal candidates from which to select a $\mathrm{CEO}$ at a future date. Specifically, we examine the probability that, within five years of being hired as CFO, the individual becomes the CEO at the same firm where she is currently employed as CFO. Because we only have employment data until the end of 2013, we limit this analysis to CFOs who were hired between 2000 and 2008. We estimate the following logistic regression model:

$$
C E O_{t, t+5}=\gamma_{0}+\gamma_{1} C P A_{t}+\gamma_{2} \text { PriorCFO }_{t}+\gamma_{3} A g e_{t}+\varepsilon_{t}
$$


Table 7 presents the results of estimating Equation (3), including the corresponding average marginal effects. The results suggest that CPA CFOs are significantly less likely than non-CPA CFOs to progress to the CEO position, consistent with $\mathrm{P} 4$. The average marginal effect implies that CPA CFOs are approximately $1.1 \%$ less likely to become the CEO within five years of being hired as a CFO, which is large in magnitude given that the overall likelihood of becoming the CEO is $3.7 \%$ (Table 2 Panel A).

This evidence, combined with our earlier finding that firms are more likely to add a COO position following the appointment of an accounting expert CFO (as documented in Section 4.4) is related to the literature on CEO succession planning. Prior work suggests firms often engage in "relay" succession, in which a CEO "heir apparent" (often the COO) is designated prior to the CEO departure (Vancil 1987). For example, Naveen (2006) documents that the likelihood of having a high-level operational position increases from $41 \%$ to $60 \%$ from four years prior to CEO turnover to one year prior to CEO turnover. Thus, given that CPA CFOs are less likely to be promoted to CEO, it appears that boards establish a COO position following the appointment of an accounting expert CFO to establish a viable heir apparent. Overall, these results are consistent with our main hypothesis that accounting expertise entails costs in terms of a tradeoff with general management skills that would be useful for non-accounting related job responsibilities.

\subsection{Robustness analyses}

\subsubsection{Observability of demand for accounting and non-accounting expertise}

In our analysis of the determinants of hiring an accounting expert CFO (tests of P1), most of our proxies for the demand for accounting and non-accounting related expertise are based on firm characteristics in the year prior to hire. One concern with this approach is that these firm characteristics might not represent the firm's needs going forward. Although there is evidence from prior literature that, on average, managers are not hired to implement 
significant changes to firm characteristics or policies (Pan 2017), we acknowledge that in some cases this is not true. In these situations managers are still matched to meet the firm's needs; however, these needs are less observable prior to hire, which reduces our ability to predict the expertise of the CFOs they hire. ${ }^{23}$

To provide evidence that firm characteristics prior to the hiring event generally represent the needs of the firm going forward, we separately examine the predictive strength of our model based on four proxies for the expected stability of the firm's operating environment. These proxies include the following (see Appendix A for variable definitions): 1) a significant operational change or event in the first full year of the CFO's tenure $\left(O p\right.$ Change $\left._{t+1}\right)$, based on the assumption the firm anticipates large operational changes; 2) a large return shock in the year preceding the CFO's hire (RetShock t-1 , which is more likely to be associated with significant subsequent changes at the firm; 3) high return volatility in the year preceding the CFO's hire (RetVol $\left.l_{t-1}\right)$; 4) externally hired CFOs (ExtHire), based on prior evidence that firms hiring external candidates are more likely to make changes to the firm (Huson et al. 2004). We expect that the four events listed above raise the likelihood that characteristics at $t-1$ are less representative of the firm's needs going forward. Thus, for each of the four events we divide our sample into two subsamples based on whether the firm experienced the event; we then estimate our hiring model separately on the two subsamples. We expect that, collectively, the independent variables in our model will be more predictive

\footnotetext{
${ }^{23}$ The fact that we find significant associations between our proxies for the demand for accounting and nonaccounting expertise and CFO expertise suggests that, on average, "hiring for change" is not overwhelmingly pervasive in our sample. That is, if the firm's characteristics at $t-1$ are not a good indication of its needs going forward, our tests are biased against finding a significant association between these characteristics and the type of CFO the firm hires. Evidence that declines in CFO-firm fit (based on significant changes in our proxies) are associated with higher CFO turnover also suggests that, on average, firm characteristics at $t-1$ are indicative of the firm's needs going forward.
} 
of the hiring outcome for the subsample with more stable operating environments (i.e., not experiencing the event). ${ }^{24}$

Our test statistic is the difference in the Pseudo $\mathrm{R}^{2}$ between the two subsamples. Because the distribution of the test statistic is unknown, we conduct a randomization test to generate a null distribution of the difference between the predictive strength of the model based on random assignment of each observation (see Appendix B for additional details on this procedure). We use this null distribution to test the significance of the difference in the Pseudo $\mathrm{R}^{2}$.

Table 8 presents the results of this analysis. Panel A presents results using our full hiring model including control variables (the model reported in Column (5) of Table 4), and Panel B reports results excluding the control variables (Column (4) of Table 4). In each case across the two panels, the Pseudo $\mathrm{R}^{2}$ from our hiring model is smaller for the subsample undergoing a potential change. For example, the Pseudo $\mathrm{R}^{2}$ from the hiring model is $2.2 \%$ for firm-years classified as having an operating change versus 3.1\% for firm-years classified as not having an operating change. This difference is statistically significant with a p-value of 0.03 (i.e., in our randomization procedure, only $3 \%$ of the trials resulted in test statistics greater than the actual test statistic). This result provides further evidence that the hiring model reflects firm-manager matching notwithstanding potential measurement error in the independent variables - that is, the model is more predictive when the needs of the firm are more stable, and therefore, more observable.

\footnotetext{
${ }^{24} \mathrm{We}$ examine differences across the subsamples in terms of the total explanatory power, which reflects the combined effect of all the variables, rather than differences in individual coefficients because the motivations to "hire to change" likely vary across firms. For instance, one firm may hire an M\&A expert CFO when the firm anticipates M\&A activity after a period of no activity; others may hire to improve the firm's analyst coverage or to improve cost control, etc. As a result, only a fraction of the data is likely to support differences across the subsamples on any given coefficient.
} 


\subsubsection{Demand for non-accounting expertise}

Our inferences with respect to P1 and P2 are valid only to the extent our proxies reflect firms' demand for accounting and non-accounting expertise. To provide further validation of our proxies, we consider whether they can be used to predict the hiring of a "generalist" CFO. We proxy for general management expertise using $M B A$ because, like $C P A$, it is easily measured in a large sample and MBA CFOs are likely to have relatively diverse experiences and skill sets. Thus, we expect that the propensity to hire an MBA CFO is increasing (decreasing) in the demand for non-accounting (accounting) expertise. To test this idea, we estimate an amended version of Equation (1) by replacing the dependent variable $C P A$ with $M B A$.

The results of these analyses (untabulated) show that firms are more likely to hire a generalist CFO when they follow a product differentiation strategy (i.e., higher gross margin) have higher analyst following, more complex operations, or higher levels of investment. These results are consistent with the notion that firms prefer to hire a generalist CFO when they have a greater demand for general management skills. We also find that firms with greater industry-level accounting complexity are less likely to hire MBA CFOs, consistent with boards recognizing that generalist CFOs are less likely to have expertise to handle complex accounting issues. This evidence increases our confidence that our proxies are capturing firms' needs for accounting related and non-accounting related expertise. However, we recognize that because $M B A$ is negatively correlated with $C P A(-0.19)$, this evidence is not independent from our earlier analysis of the determinants of hiring a CPA CFO and should be interpreted accordingly.

\subsubsection{Measurement of accounting expertise}

Throughout our paper, we define accounting expert CFOs as those individuals who have received a CPA (or equivalent) certification. Although we provide evidence that, on 
average, CPA CFOs have less finance, operational, and general management experience, it is likely that some subset of our CPA CFOs also develop non-accounting related expertise (through education or work experience). For example, the descriptive statistics in Table 2 indicate that $29 \%$ of our CPA hires also have an MBA. Similarly, it is possible that older CPA CFOs develop more non-accounting skills over time. We test the sensitivity of our results to this classification decision. Specifically, we re-estimate all of our analyses excluding 1) CFOs that have both a CPA and an MBA, and 2) CFOs in the top quartile of age. In general, we find inferentially similar results with these adjustments (untabulated), although significance levels are lower for certain tests. ${ }^{25}$

\section{Conclusion}

This paper examines the tradeoffs of accounting expertise. We first provide evidence that acquiring accounting expertise requires a tradeoff in terms of acquiring other skills and knowledge (e.g., finance or general management). Consistent with these tradeoffs being significant for firms' CFO hiring decisions, we find that a firm's propensity to hire a CPA CFO, our proxy for an accounting expert, is increasing (decreasing) in the demand for accounting expertise (non-accounting expertise) in the CFO position. Analyses of subsequent employment decisions further illustrate the significance of the tradeoffs of CFO accounting expertise. We show that significant declines in the fit between the CFO and the firm's needs after initial appointment are associated with a higher probability of CFO turnover. We also find evidence that changes in $\mathrm{CFO}$ accounting expertise at a firm are associated with changes in the composition of the top management team, consistent with firms making hiring decisions to complement CFOs' skill sets. Further, we find that CPA CFOs are less likely to become CEOs at the same firm in the five years following their CFO appointment, consistent

\footnotetext{
${ }^{25}$ For example, in Table 6, Panel A (change in existence of a COO position), the p-value is 0.17 when dropping older CFOs, perhaps because of a large decrease in sample size (from 838 to 494) due to missing ages for some observations. The majority of the remaining tests are significant at the $10 \%$ level or better.
} 
with accounting expert CFOs having a lower option value to potentially advance to the CEO position.

Overall, our results suggest that boards recognize the tradeoffs in CFOs' skill sets and carefully weigh the presence of accounting expertise on the top management team. These results have important implications for the literature that examines the effects of manager characteristics on firm policies and outcomes. Identifying the effects of specific manager characteristics on firm outcomes is complicated by firms' actions to compensate for deficiencies in managers' skill sets through organizational design choices. That is, because the tradeoffs inherent in managers' characteristics affect the structure and composition of the top management team, most firm outcomes are likely to be noisy proxies for the costs and benefits of a specific manager's skill set. Our findings also highlight that efficient matching between firms and managers can diminish empirical relations between manager characteristics and firm outcomes, which would not necessarily suggest that there are no tradeoffs associated with the characteristic. ${ }^{26}$

More broadly, our study contributes to the literature on the matching of managers' skills with firms' needs and highlights potential costs of acquiring accounting expertise. These findings are likely to be informative for boards of directors in their hiring decisions and managers for their career development.

\footnotetext{
${ }^{26}$ For example, a firm with greater financial reporting complexity might be more likely to have accounting restatements but also more likely to hire an accounting expert CFO. Thus, with efficient matching between firms and managers, the negative effect of accounting expertise on restatements can be offset in whole or in part by the positive effect of reporting complexity on restatements.
} 


\section{References}

Aier, J., J. Comprix, M. Gunlock, and D. Lee. 2005. The financial expertise of CFOs and accounting restatements. Accounting Horizons 19: 123-135.

Bertrand, M. and A. Schoar. 2003. Managing with style: The effect of managers on firm policies. The Quarterly Journal of Economics 118: 1169-1208.

Brochet, F. and K. Welch. 2011. Top executive background and financial reporting choice. Working paper, Boston University and Harvard Business School.

Chen, G. and D. Hambrick. 2012. CEO replacement in turnaround situations: Executive (mis)fit and its performance implications. Organization Science 23: 225-243.

Consero Group LLC. 2013. 2013 Chief Financial Officer Data Survey.

Custodio, C., M. Ferreira, and P. Matos. 2013. Generalists versus specialists: Lifetime work experience and chief executive officer pay. Journal of Financial Economics 108: 471492.

DeFond, M., R. Hann, and X. Hu. 2005. Does the market value financial expertise on audit committees of boards of directors? Journal of Accounting Research 43: 153-193.

Ernst \& Young. 2010. The DNA of the CFO: A study of what makes a chief financial officer.

Favaro, P. 2001. Beyond bean counting: The CFO's expanding role. Strategy \& Leadership 29: 4-8.

Finkelstein, S., D. C. Hambrick, and J. Cannella. 2009. Strategic leadership: Theory and research on executives, top management teams, and boards. Oxford, UK: Oxford University Press.

Ge, W., D. Matsumoto, and J. Zhang. 2011. Do CFOs have style? An empirical investigation of the effect of individual CFOs on accounting practices. Contemporary Accounting Research 28: 1141-1179.

Groysberg, B., L. Kelly, and B. MacDonald. 2011. The new path to the C-Suite. Harvard Business Review 89: 2-10.

Hambrick, D., and P. Mason. 1984. Upper echelons: The organization as a reflection of its top managers. The Academy of Management Review 9: 193-206.

Hoberg, G., and G. Phillips. 2010. Product market synergies and competition in mergers and acquisitions: A text-based analysis. Review of Financial Studies 23: 3773-3811.

Hoitash, R., U. Hoitash, and A. Kurt. 2016. Do accountants make better chief financial officers? Journal of Accounting and Economics 61: 414-432.

Huson, M., P. H. Malatesta, and R. Parrino. 2004. Managerial succession and firm performance. Journal of Financial Economics 74: 237-275.

Li, C., L. Sun, and M. Ettredge. 2010. Financial executive qualifications, financial executive turnover, and adverse SOX 404 opinions. Journal of Accounting and Economics 50: 93110.

Li, F., M. Minnis, V. Nagar, and M. Rajan. 2014. Knowledge, compensation, and firm value: An empirical analysis of firm communication. Journal of Accounting and Economics 58: 96-116.

Lundholm, R., and L. A. Myers. 2002. Bringing the future forward: The effect of disclosure on the returns-earnings relation. Journal of Accounting Research 40: 809-839.

Mian, S. 2001. On the choice and replacement of chief financial officers. Journal of Financial Economics 60: 143-175.

Naveen, L. 2006. Organizational complexity and succession planning. The Journal of Financial and Quantitative Analysis 41: 661-683.

Owens, E. L., J. S. Wu, and J. L. Zimmerman. 2016. Idiosyncratic shocks to firm underlying economics and abnormal accruals. The Accounting Review (forthcoming). 
Pan, Y. 2017. The determinants and impact of executive-firm matches. Management Science 63: $185-200$.

Peterson, K. 2012. Accounting complexity, misreporting, and the consequences of misreporting. Review of Accounting Studies 17: 72-95.

Shen, W., and A. A. Cannella. 2002. Revisiting the performance consequences of CEO succession: The impacts of successor type, postsuccession senior executive turnover, and departing CEO tenure. Academy of Management Journal 45: 717-733.

Vancil, R. 1987. Passing the baton. Boston, MA: Harvard University Press.

Wang, X. 2010. Increased disclosure requirements and corporate governance decisions: Evidence from chief financial officers in the pre- and post-Sarbanes-Oxley periods. Journal of Accounting Research 48: 885-920.

Westphal, J., and E. Zajac. 1995. Who shall govern? CEO/board power, demographic similarity, and new director selection. Administrative Science Quarterly 40: 60-83.

Zhang, Y., and N. Rajagopalan. 2003. Explaining new CEO origin: Firm versus industry antecedents. Academy of Management Journal 46: 327-338. 


\section{Appendix A: Variable definitions}

\begin{tabular}{|c|c|}
\hline Variable Name & Definition \\
\hline $\mid$ Accruals $\mid$ & $\begin{array}{l}\text { Absolute value of total accruals, scaled by total assets (Compustat items } \\
(|\mathrm{IBC}-\mathrm{OANCF}|) / \mathrm{AT})\end{array}$ \\
\hline$\Delta \mathrm{CPA} \mathrm{Fit}_{\mathrm{t}+\mathrm{n}}$ & $\begin{array}{l}\text { Predicted value of Equation }(1) \text { in each year subsequent to the CFO's } \\
\text { date of hire less the predicted value at the hire date }(n=0) \text {, scaled by the } \\
\text { predicted value at the hire date. }\end{array}$ \\
\hline Acctg & $\begin{array}{l}\text { Indicator variable equal to one if the firm has an individual other than } \\
\text { the CFO with the term "Accounting" or "Controller" in the role } \\
\text { description, and zero otherwise }\end{array}$ \\
\hline AddAcctg & $\begin{array}{l}\text { Indicator variable equal to one if the firm did not have an accounting } \\
\text { related position in the year prior to the CFO's hire but does by the end } \\
\text { of the second calendar year after the CFO's hire and zero otherwise }\end{array}$ \\
\hline AddCOO & $\begin{array}{l}\text { Indicator variable equal to one if the firm did not have a COO in the } \\
\text { year prior to the CFO's hire but does by the end of the second calendar } \\
\text { year after the CFO's hire and zero otherwise }\end{array}$ \\
\hline AddCPA & $\begin{array}{l}\text { Indicator variable equal to one if the CFO hired has a CPA and the prior } \\
\text { CFO did not (where data is available) and zero otherwise }\end{array}$ \\
\hline Age & Age of the $\mathrm{CFO}$ \\
\hline AnalystFollow & $\begin{array}{l}\text { Natural } \log \text { of } 1+\text { maximum number of estimates used in calculating a } \\
\text { consensus EPS forecast for the firm at any point during the fiscal year. } \\
\text { Missing values are set to zero. }\end{array}$ \\
\hline BM & Book-to-market (Compustat items CEQ/(CSHO*PRCC_F)) \\
\hline BoardSeat & $\begin{array}{l}\text { Indicator variable equal to one if the CFO held a board seat at a public } \\
\text { company at the time they were hired as CFO at the sample firm }\end{array}$ \\
\hline CEOCPA & $\begin{array}{l}\text { Indicator variable equal to one if the CEO has a CPA or Chartered } \\
\text { Accountant qualification, and zero otherwise }\end{array}$ \\
\hline CEOTenure & $\begin{array}{l}\text { Tenure of the CEO (in years) at the time the CFO was hired at the } \\
\text { sample firm }\end{array}$ \\
\hline $\mathrm{CEO}_{\mathrm{t}, \mathrm{t}+5}$ & $\begin{array}{l}\text { Indicator variable equal to one if the CFO became CEO of the same } \\
\text { firm within } 5 \text { years of being initially hired as a CFO at the sample firm, } \\
\text { and zero otherwise }\end{array}$ \\
\hline CFA & $\begin{array}{l}\text { Indicator variable equal to one if the CFO has a CFA qualification, and } \\
\text { zero otherwise }\end{array}$ \\
\hline CFOExit $_{\mathrm{t}+\mathrm{n}+1}$ & $\begin{array}{l}\text { Indicator variable equal to one if the CFO departs the firm during fiscal } \\
\text { year } t+n+1 \text {, where year } t \text { is the hire year }\end{array}$ \\
\hline $\mathrm{COO}$ & $\begin{array}{l}\text { Indicator variable equal to one if the firm has an individual other than } \\
\text { the CFO with the title COO or Vice President of Operations }\end{array}$ \\
\hline CPA & $\begin{array}{l}\text { Indicator variable equal to one if the CFO has a CPA or Chartered } \\
\text { Accountant qualification, and zero otherwise }\end{array}$ \\
\hline Distress & $\begin{array}{l}\text { Indicator variable equal to one if the firm reports negative book value of } \\
\text { equity (Compustat item CEQ) }\end{array}$ \\
\hline DropAcctg & $\begin{array}{l}\text { Indicator variable equal to one if the firm had an accounting related } \\
\text { position in the year prior to the CFO's hire but did not at the end of the } \\
\text { second calendar year after the CFO's hire and zero otherwise }\end{array}$ \\
\hline DropCOO & $\begin{array}{l}\text { Indicator variable equal to one if the firm had a COO in the year prior to } \\
\text { the CFO's hire but did not at the end of the second calendar year after } \\
\text { the CFO's hire and zero otherwise }\end{array}$ \\
\hline DropCPA & $\begin{array}{l}\text { Indicator variable equal to one if the CFO hired does not have a CPA } \\
\text { and the prior CFO did (where data is available) and zero otherwise }\end{array}$ \\
\hline ExtHire & $\begin{array}{l}\text { Indicator variable equal to one if the CFO position was the first position } \\
\text { the individual held at the company, as reported on BoardEx }\end{array}$ \\
\hline FIN & Indicator variable equal to one if the executive has prior work \\
\hline
\end{tabular}


GeoSeg

GrossMargin

IndGrossMargin

IB Experience

ICW

IndComplexity

Investment

Lev

MA

IndMA

MBA

MVE

OpChange

PoorFit

PriorCFO

Prop Public US Exp

Ret

RetShock

RetVol

ROA

SOX

Tenure experience at an investment banking firm or they hold a CFA

qualification and zero otherwise

Log of number of geographic segments at the firm

Gross margin (Compustat items (SALE-COGS)/SALE)

Median industry gross margin; industry defined at the 3-digit SIC code

Indicator variable equal to one if the $\mathrm{CFO}$ has prior experience listed in

BoardEx from an investment bank, and zero otherwise

Indicator variable equal to one if the firm reported an internal control

weakness

Natural log of 1+average number of non-fraud restatements in the firm's 3 -digit SIC industry group

Natural $\log$ of $1+$ capital expenditures plus research and development, scaled by sales (Compustat items (CAPX+XRD)/SALE)

Leverage, where values greater than 1 are winsorized to 1 (Compustat items (DLC+DLTT)/AT)

Natural $\log$ of $1+$ number of acquisitions the firm made in the most recent 365 days

Natural log of one plus the total number of acquisitions of an industry in the most recent 365 days; industry defined at the 3-digit SIC code

Indicator variable equal to one if the CFO holds an MBA degree, and zero otherwise

Market value of equity (Compustat items CSHO*PRCC_F)

Indicator variable equal to one if any of the following criteria hold: (1)

special items, discontinued operations, or restructuring charges are

greater than $5 \%$ of sales, (2) the firm experienced a change in their

industry (either NAICS or SIC), or (3) sales have been "restated

for/reflects a major merger or reorganization resulting in the formation

of a new company" (Owens et al. 2016) and zero otherwise

Indicator variable equal to one if the CFO hired at the sample firm is a

non-CPA (CPA) and $\triangle \mathrm{CPA}$ _Fit is in the top (bottom) quintile of the

distribution

Indicator variable equal to one if the $\mathrm{CFO}$ has prior experience as a $\mathrm{CFO}$ of a public company

Proportion of prior years of experience listed on BoardEx spent at a US public company

Market adjusted buy and hold annual returns

Indicator variable equal to one if the maximum absolute monthly return in the year prior to the CFO's hire is above the mean in our sample and zero otherwise

Indicator variable equal to one if the firm's stock return volatility in the year prior to the CFO's hire is above the mean in our sample and zero otherwise

Return on assets (Compustat items OIADP/AT)

Indicator variable equal to one if the CFO was hired between 2004 and 2006 (inclusive) and zero otherwise

Tenure in the CFO position at the sample firm (missing when BoardEx indicates the individual was CFO at the firm in 2013) 


\section{Appendix B: Description of randomization tests to assess differences in predictive strength of hiring model}

In Table 8 , we report the Pseudo $\mathrm{R}^{2}$ from estimating our hiring model on various subsamples of firm-years identified as undergoing significant change versus remaining stable. To test the significance of the difference in Pseudo $\mathrm{R}^{2} \mathrm{~s}$ between the subsamples, we use a randomization test similar to that used in Lundholm and Myers (2002) and described further below.

We first calculate the test statistic, which represents the difference in the Pseudo $\mathrm{R}^{2}$ of Equation (1) for each subsample of firms (e.g., for those with $O p$ Change $_{t+1}=0$ and those with OpChang $_{t+1}=1$ ). We then randomly assign firms to each group, ensuring that the number of firms in each subsample is held constant with each randomization. For instance, within our sample, 4,950 $(1,506)$ observations were used to calculate the Pseudo $\mathrm{R}^{2}$ for the OpChange $_{t+1}=0\left(\right.$ OpChange $\left._{t+1}=1\right)$ subsamples. Therefore, when calculating the null distribution for this subsample grouping variable, we randomly assign 4,950 observations from this potential sample of 6,456 observations to the non-operating change subsample and 1,506 to the operating change subsample. This ensures that the null distribution of the test statistic is not affected by differences in the sample size used. Once firms are randomly assigned into a subsample, we re-estimate the test statistic. We repeat this random assignment and re-estimation 999 times, which gives us a distribution of the test statistic under the null hypothesis of no difference in the predictive ability of our model between firms that experienced an operating change in year $t+1$ and those that did not. The significance level of the test statistic is $(\mathrm{NGE}+1) / 1000$, where NGE represents the number of test statistics from the null distribution that is at least as large as our calculated test statistic (e.g., 0.009 for OpChang $\left.e_{t+1}\right){ }^{28}$

\footnotetext{
${ }^{28}$ We perform this procedure numerous times and although the specific $p$-value changes in each trial due to the randomization, our inferences are unchanged with respect to the significance level at conventional cutoffs.
} 
Figure 1: Variable measurement timeline

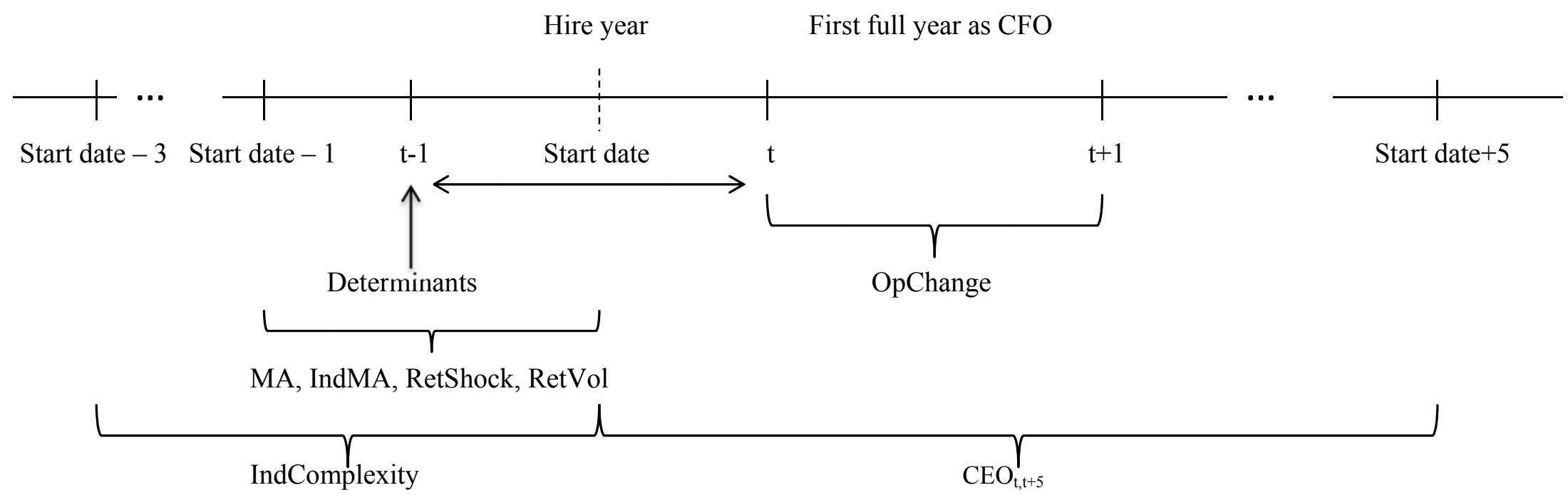

This figure presents an overview of the timing of variable measurement for our main analyses. See Appendix A for the variable definitions. "Determinants" includes the financial statement and top management team variables used in Table 4. 
Figure 2: CPA hires over time

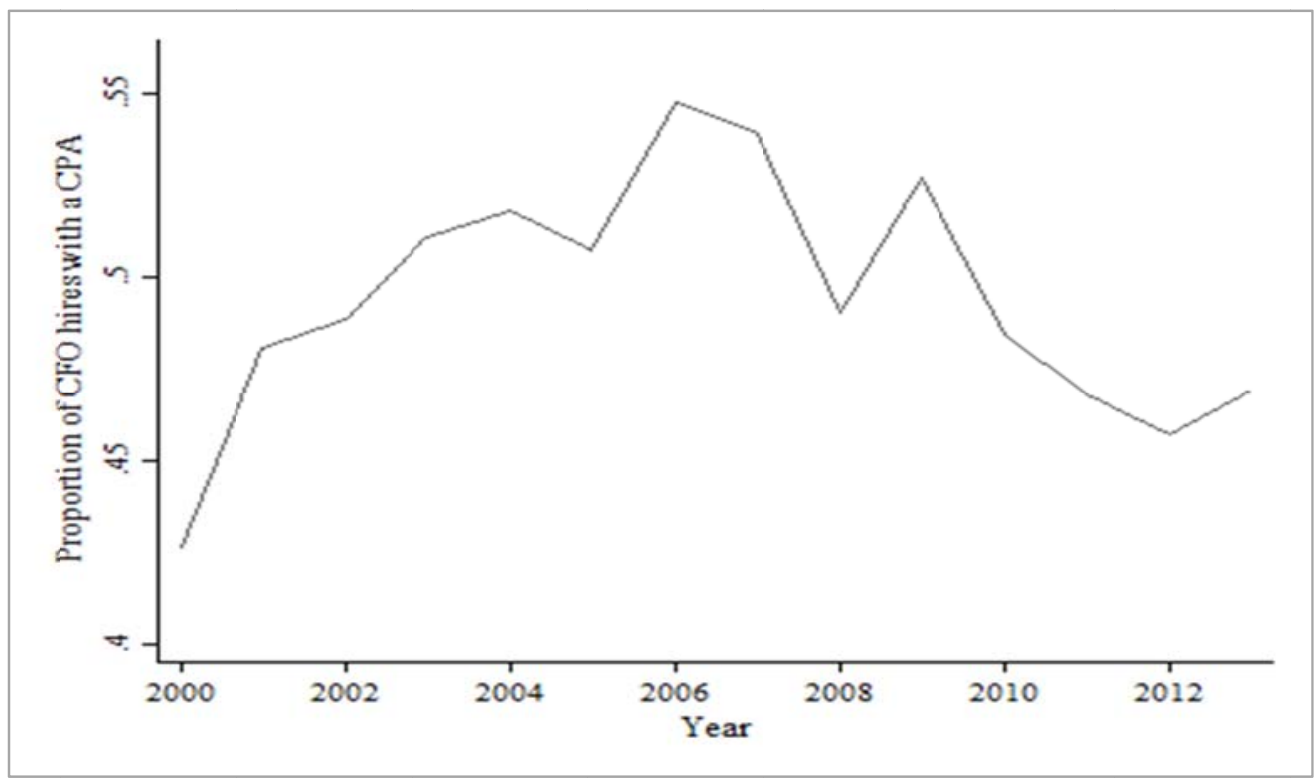

This figure presents a time plot, by year, of the proportion of CFOs hired who have received a CPA or international equivalent. The underlying data are tabulated in Table 1, Panel B. 
Table 1, Panel A: Sample selection

Number of

observations

CFOs hired from 2000-2013 at publicly traded U.S. companies 13,908 (excluding dual CEO-CFO positions and CFOs that were previously employed as $\mathrm{CFO}$ at the same firm)

Less: Divisional, regional, deputy, or co-CFOs

Less: Observations with missing CIK codes on BoardEx

Less: CFOs that were employed for less than a complete fiscal year

Less: Multiple CFOs hired in the same calendar year

Less: Firm-years with missing assets

Sample of CFO hires

8,497

Note: Actual sample sizes differ depending on availability of control variables

Table 1, Panel B: Sample distribution

\begin{tabular}{lcccc} 
Year & CFO hires & CPA hires & $\begin{array}{c}\text { Non-CPA } \\
\text { hires }\end{array}$ & $\begin{array}{c}\text { Proportion of CFO hires } \\
\text { with a CPA }\end{array}$ \\
\hline 2000 & 647 & 276 & 371 & 0.427 \\
2001 & 624 & 300 & 324 & 0.481 \\
2002 & 657 & 321 & 336 & 0.489 \\
2003 & 636 & 325 & 311 & 0.511 \\
2004 & 708 & 367 & 341 & 0.518 \\
2005 & 733 & 372 & 361 & 0.508 \\
2006 & 732 & 401 & 331 & 0.548 \\
2007 & 690 & 372 & 318 & 0.539 \\
2008 & 646 & 317 & 329 & 0.491 \\
2009 & 444 & 234 & 210 & 0.527 \\
2010 & 487 & 236 & 251 & 0.485 \\
2011 & 457 & 214 & 243 & 0.468 \\
2012 & 531 & 243 & 288 & 0.458 \\
2013 & 505 & 237 & 268 & 0.469 \\
\hline Total & $\mathbf{8 , 4 9 7}$ & $\mathbf{4 , 2 1 5}$ & $\mathbf{4 , 2 8 2}$ & $\mathbf{0 . 4 9 6}$
\end{tabular}


Table 2: Descriptive statistics

\begin{tabular}{lcccccc} 
Panel A: Full sample & & & & & & \\
Variable & $\mathrm{N}$ & Mean & 25 th $\%$ & Median & 75 th \% & Std Dev \\
\hline CPA & 8,497 & 0.496 & 0.000 & 0.000 & 1.000 & 0.500 \\
MBA & 8,497 & 0.382 & 0.000 & 0.000 & 1.000 & 0.486 \\
FIN & 8,497 & 0.101 & 0.000 & 0.000 & 0.000 & 0.301 \\
PriorCFO & 8,497 & 0.336 & 0.000 & 0.000 & 1.000 & 0.472 \\
Prop Public US Exp & 6,913 & 0.335 & 0.000 & 0.204 & 0.639 & 0.369 \\
BoardSeat & 8,497 & 0.157 & 0.000 & 0.000 & 0.000 & 0.364 \\
ExtHire & 8,497 & 0.598 & 0.000 & 1.000 & 1.000 & 0.490 \\
Age & 6,719 & 47.686 & 43.000 & 48.000 & 53.000 & 6.997 \\
Tenure & 5,247 & 4.063 & 2.359 & 3.490 & 5.208 & 2.202 \\
CEO & 8,497 & 0.037 & 0.000 & 0.000 & 0.000 & 0.189 \\
IndComplexity $_{\text {t- } 3, t-1}$ & 8,497 & 1.885 & 0.847 & 1.792 & 2.909 & 1.390 \\
$\mid$ Accruals $_{\mathrm{t}-1}$ & 7,685 & 0.113 & 0.027 & 0.059 & 0.121 & 0.177 \\
ICW $_{\mathrm{t}-1}$ & 8,497 & 0.048 & 0.000 & 0.000 & 0.000 & 0.213 \\
GeoSeg $_{\mathrm{t}-1}$ & 8,497 & 0.476 & 0.000 & 0.000 & 1.099 & 0.656 \\
Distress $_{\mathrm{t}-1}$ & 8,104 & 0.084 & 0.000 & 0.000 & 0.000 & 0.277 \\
Investment $_{\mathrm{t}-1}$ & 7,810 & 0.196 & 0.019 & 0.059 & 0.169 & 0.435 \\
AnalystFollow $_{\mathrm{t}-1}$ & 8,497 & 1.017 & 0.000 & 0.000 & 2.197 & 1.199 \\
MA $_{\mathrm{t}-1}$ & 8,497 & 0.232 & 0.000 & 0.000 & 0.000 & 0.458 \\
IndMA $_{\mathrm{t}-1}$ & 8,497 & 3.718 & 2.890 & 3.871 & 4.812 & 1.470 \\
GrossMargin $_{\mathrm{t}-1}$ & 7,926 & 0.103 & 0.212 & 0.380 & 0.581 & 1.991 \\
IndGrossMargin $_{\mathrm{t}-1}$ & 8,497 & 0.397 & 0.277 & 0.393 & 0.514 & 0.154 \\
Acctg $_{\mathrm{t}-1}$ & 8,497 & 0.388 & 0.000 & 0.000 & 1.000 & 0.487 \\
CEOCPA $_{\mathrm{t}-1}$ & 8,497 & 0.063 & 0.000 & 0.000 & 0.000 & 0.243 \\
COO $_{\mathrm{t}-1}$ & 8,497 & 0.515 & 0.000 & 1.000 & 1.000 & 0.500 \\
ROA $_{\mathrm{t}-1}$ & 8,096 & -0.023 & -0.016 & 0.041 & 0.098 & 0.286 \\
BM $_{\mathrm{t}-1}$ & 8,232 & 0.561 & 0.123 & 0.422 & 0.774 & 0.629 \\
Lev $_{\mathrm{t}-1}$ & 8,130 & 0.232 & 0.021 & 0.173 & 0.359 & 0.237 \\
Ln & 6,961 & 5.970 & 4.493 & 5.912 & 7.349 & 2.098 \\
\hline
\end{tabular}


Table 2, Continued. Panel B: Descriptive statistics by CFO type

\begin{tabular}{|c|c|c|c|c|c|c|c|c|}
\hline \multirow[b]{2}{*}{ Variable } & \multicolumn{3}{|c|}{ CPA } & \multicolumn{3}{|c|}{ Non-CPA } & \multicolumn{2}{|l|}{ Mean } \\
\hline & $\mathrm{N}$ & Mean & Median & $\mathrm{N}$ & Mean & Median & Difference & p-value \\
\hline MBA & 4,215 & 0.289 & 0.000 & 4,282 & 0.473 & 0.000 & $-0.184 * * *$ & 0.000 \\
\hline FIN & 4,215 & 0.044 & 0.000 & 4,282 & 0.157 & 0.000 & $-0.114 * * *$ & 0.000 \\
\hline PriorCFO & 4,215 & 0.350 & 0.000 & 4,282 & 0.322 & 0.000 & $0.028 * * *$ & 0.007 \\
\hline Prop Public US Exp & 3,471 & 0.306 & 0.000 & 3,442 & 0.365 & 0.000 & $-0.058 * * *$ & 0.000 \\
\hline BoardSeat & 4,215 & 0.134 & 0.000 & 4,282 & 0.180 & 0.000 & $-0.047 * * *$ & 0.000 \\
\hline ExtHire & 4,215 & 0.606 & 0.000 & 4,282 & 0.590 & 0.000 & 0.016 & 0.138 \\
\hline Age & 3,369 & 47.272 & 42.000 & 3,350 & 48.103 & 43.000 & $-0.831 * * *$ & 0.000 \\
\hline Tenure & 2,573 & 3.981 & 2.307 & 2,674 & 4.142 & 2.411 & $-0.160 * * *$ & 0.008 \\
\hline $\mathrm{CEO}_{\mathrm{t}, \mathrm{t}+5}$ & 4,215 & 0.033 & 0.000 & 4,282 & 0.041 & 0.000 & $-0.008^{*}$ & 0.062 \\
\hline IndComplexity ${ }_{\mathrm{t}-3, \mathrm{t}-1}$ & 4,215 & 1.945 & 0.981 & 4,282 & 1.827 & 0.847 & $0.118 * * *$ & 0.000 \\
\hline $\mid$ Accruals $_{\mathrm{t}-1} \mid$ & 3,824 & 0.116 & 0.027 & 3,861 & 0.110 & 0.026 & 0.006 & 0.147 \\
\hline $\mathrm{ICW}_{\mathrm{t}-1}$ & 4,215 & 0.054 & 0.000 & 4,282 & 0.042 & 0.000 & $0.012 * * *$ & 0.009 \\
\hline $\operatorname{GeoSeg}_{\mathrm{t}-1}$ & 4,215 & 0.444 & 0.000 & 4,282 & 0.508 & 0.000 & $-0.064 * * *$ & 0.000 \\
\hline Distress $_{\mathrm{t}-1}$ & 4,023 & 0.075 & 0.000 & 4,081 & 0.093 & 0.000 & $-0.019 * * *$ & 0.002 \\
\hline Investment $_{t-1}$ & 3,881 & 0.191 & 0.017 & 3,929 & 0.201 & 0.020 & -0.009 & 0.349 \\
\hline AnalystFollow $_{\mathrm{t}-1}$ & 4,215 & 0.925 & 0.000 & 4,282 & 1.108 & 0.000 & $-0.182 * * *$ & 0.000 \\
\hline $\mathrm{MA}_{\mathrm{t}-1}$ & 4,215 & 0.216 & 0.000 & 4,282 & 0.249 & 0.000 & $-0.033 * * *$ & 0.001 \\
\hline IndMA $_{\mathrm{t}-1}$ & 4,215 & 3.749 & 2.944 & 4,282 & 3.689 & 2.890 & $0.060 *$ & 0.061 \\
\hline GrossMargin $_{\mathrm{t}-1}$ & 3,936 & 0.084 & 0.213 & 3,990 & 0.121 & 0.212 & -0.037 & 0.409 \\
\hline IndGrossMargin $_{\mathrm{t}-1}$ & 4,215 & 0.399 & 0.284 & 4,282 & 0.394 & 0.274 & 0.005 & 0.176 \\
\hline $\operatorname{Acctg}_{\mathrm{t}-1}$ & 4,215 & 0.338 & 0.000 & 4,282 & 0.437 & 0.000 & $-0.098 * * *$ & 0.000 \\
\hline $\mathrm{CEOCPA}_{\mathrm{t}-1}$ & 4,215 & 0.070 & 0.000 & 4,282 & 0.056 & 0.000 & $0.014 * * *$ & 0.007 \\
\hline $\mathrm{COO}_{\mathrm{t}-1}$ & 4,215 & 0.518 & 0.000 & 4,282 & 0.512 & 0.000 & 0.006 & 0.565 \\
\hline $\mathrm{ROA}_{\mathrm{t}-1}$ & 4,020 & -0.026 & -0.023 & 4,076 & -0.019 & -0.009 & -0.007 & 0.290 \\
\hline $\mathrm{BM}_{\mathrm{t}-1}$ & 4,086 & 0.567 & 0.136 & 4,146 & 0.555 & 0.111 & 0.013 & 0.361 \\
\hline $\operatorname{Lev}_{\mathrm{t}-1}$ & 4,035 & 0.225 & 0.013 & 4,095 & 0.239 & 0.029 & $-0.015 * * *$ & 0.005 \\
\hline $\operatorname{Ln}\left(\mathrm{MVE}_{\mathrm{t}-1}\right)$ & 3,477 & 5.678 & 4.327 & 3,484 & 6.263 & 4.744 & $-0.585 * * *$ & 0.000 \\
\hline
\end{tabular}

This table presents descriptive statistics for the full sample and separately for CPA and non-CPA hires. See Appendix A for variable definitions. $* * * * *, *$ indicate significance of the mean values between the CPA- and non-CPA CFO hires at the $1 \%, 5 \%$, and $10 \%$ levels respectively. 
Table 3: Correlation matrix

\begin{tabular}{|c|c|c|c|c|c|c|c|c|}
\hline & $\begin{array}{r}\text { (1) } \\
\text { CPA }\end{array}$ & $\begin{array}{c}(2) \\
\text { MBA }\end{array}$ & $\begin{array}{l}\text { (3) } \\
\text { FIN }\end{array}$ & $\begin{array}{l}(4) \\
\text { Prior } \\
\text { CFO }\end{array}$ & $\begin{array}{c}(5) \\
\text { Prop Public } \\
\text { US Exp }\end{array}$ & $\begin{array}{c}\text { (6) } \\
\text { BoardSeat }\end{array}$ & $\begin{array}{c}\text { (7) } \\
\text { ExtHire }\end{array}$ & Age \\
\hline (2) $\mathrm{MBA}$ & $\begin{array}{l}-0.189 \\
(0.000)\end{array}$ & & & & & & & \\
\hline (3) FIN & $\begin{array}{l}-0.189 \\
(0.000)\end{array}$ & $\begin{array}{c}0.136 \\
(0.000)\end{array}$ & & & & & & \\
\hline (4) Prior CFO & $\begin{array}{c}0.029 \\
(0.007)\end{array}$ & $\begin{array}{c}0.100 \\
(0.000)\end{array}$ & $\begin{array}{l}-0.028 \\
(0.011)\end{array}$ & & & & & \\
\hline (5) Prop Public US Exp & $\begin{array}{c}-0.083 \\
(0.000)\end{array}$ & $\begin{array}{c}0.146 \\
(0.000)\end{array}$ & $\begin{array}{c}0.003 \\
(0.787)\end{array}$ & $\begin{array}{c}0.352 \\
(0.000)\end{array}$ & & & & \\
\hline (6) BoardSeat & $\begin{array}{l}-0.064 \\
(0.000)\end{array}$ & $\begin{array}{c}0.051 \\
(0.000)\end{array}$ & $\begin{array}{c}0.064 \\
(0.000)\end{array}$ & $\begin{array}{c}0.104 \\
(0.000)\end{array}$ & $\begin{array}{c}0.037 \\
(0.002)\end{array}$ & & & \\
\hline (7) ExtHire & $\begin{array}{c}0.015 \\
(0.156)\end{array}$ & $\begin{array}{c}0.117 \\
(0.000)\end{array}$ & $\begin{array}{c}0.048 \\
(0.000)\end{array}$ & $\begin{array}{c}0.335 \\
(0.000)\end{array}$ & $\begin{array}{c}0.104 \\
(0.000)\end{array}$ & $\begin{array}{c}0.046 \\
(0.000)\end{array}$ & & \\
\hline (8) Age & $\begin{array}{l}-0.059 \\
(0.000)\end{array}$ & $\begin{array}{c}0.076 \\
(0.000)\end{array}$ & $\begin{array}{l}-0.097 \\
(0.000)\end{array}$ & $\begin{array}{c}0.257 \\
(0.000)\end{array}$ & $\begin{array}{c}0.091 \\
(0.000)\end{array}$ & $\begin{array}{c}0.120 \\
(0.000)\end{array}$ & $\begin{array}{c}0.157 \\
(0.000)\end{array}$ & 1.000 \\
\hline
\end{tabular}

This table presents Pearson correlation coefficients between variables representing characteristics of the CFOs hired in our sample over the period 2000-2013. See Appendix A for variable definitions. p-values are presented in parentheses. 
Table 4: Determinants of hiring a CPA CFO

Panel A: Coefficient estimates

\begin{tabular}{|c|c|c|c|c|c|}
\hline VARIABLES & $\begin{array}{c}(1) \\
\operatorname{Pr}(\mathrm{CPA}=1)\end{array}$ & $\begin{array}{c}(2) \\
\operatorname{Pr}(\mathrm{CPA}=1)\end{array}$ & $\begin{array}{c}(3) \\
\operatorname{Pr}(\mathrm{CPA}=1)\end{array}$ & $\begin{array}{c}(4) \\
\operatorname{Pr}(\mathrm{CPA}=1)\end{array}$ & $\begin{array}{c}(5) \\
\operatorname{Pr}(\mathrm{CPA}=1)\end{array}$ \\
\hline $\mathrm{SOX}_{\mathrm{t}}$ & $\begin{array}{c}0.155^{* * *} \\
(2.93)\end{array}$ & & $\begin{array}{c}0.132 * * \\
(2.44)\end{array}$ & $\begin{array}{c}0.136^{* *} \\
(2.50)\end{array}$ & $\begin{array}{c}0.136^{* *} \\
(2.26)\end{array}$ \\
\hline IndComplexity $y_{t-3, t-1}$ & $\begin{array}{c}0.052 * * * \\
(3.09)\end{array}$ & & $\begin{array}{c}0.076^{* * *} \\
(2.96)\end{array}$ & $\begin{array}{c}0.079 * * * \\
(3.06)\end{array}$ & $\begin{array}{c}0.090 * * * \\
(3.14)\end{array}$ \\
\hline $\mid$ Accruals $_{\mathrm{t}-1} \mid$ & $\begin{array}{l}0.147 \\
(1.13)\end{array}$ & & $\begin{array}{l}0.222 \\
(1.51)\end{array}$ & $\begin{array}{l}0.168 \\
(1.14)\end{array}$ & $\begin{array}{l}0.184 \\
(0.97)\end{array}$ \\
\hline $\mathrm{ICW}_{\mathrm{t}-1}$ & $\begin{array}{c}0.213^{* *} \\
(2.06)\end{array}$ & & $\begin{array}{l}0.199 * \\
(1.88)\end{array}$ & $\begin{array}{c}0.219^{* *} \\
(2.05)\end{array}$ & $\begin{array}{l}0.158 \\
(1.46)\end{array}$ \\
\hline $\mathrm{MA}_{\mathrm{t}-1}$ & & $\begin{array}{l}-0.082 \\
(-1.62)\end{array}$ & $\begin{array}{l}-0.065 \\
(-1.24)\end{array}$ & $\begin{array}{l}-0.047 \\
(-0.90)\end{array}$ & $\begin{array}{l}0.010 \\
(0.18)\end{array}$ \\
\hline $\operatorname{IndMA}_{\mathrm{t}-1}$ & & $\begin{array}{l}0.027 \\
(1.55)\end{array}$ & $\begin{array}{l}-0.010 \\
(-0.46)\end{array}$ & $\begin{array}{l}-0.019 \\
(-0.86)\end{array}$ & $\begin{array}{l}-0.024 \\
(-0.95)\end{array}$ \\
\hline GrossMargin $_{\mathrm{t}-1}$ & & $\begin{array}{l}-0.029^{*} \\
(-1.71)\end{array}$ & $\begin{array}{l}-0.031^{*} \\
(-1.80)\end{array}$ & $\begin{array}{l}-0.032 * \\
(-1.85)\end{array}$ & $\begin{array}{c}-0.040 * * \\
(-2.01)\end{array}$ \\
\hline IndGrossMargin $_{\mathrm{t}-1}$ & & $\begin{array}{l}0.013 \\
(0.08)\end{array}$ & $\begin{array}{l}-0.139 \\
(-0.77)\end{array}$ & $\begin{array}{l}-0.203 \\
(-1.12)\end{array}$ & $\begin{array}{c}-0.435 * * \\
(-2.17)\end{array}$ \\
\hline GeoSeg $_{t-1}$ & & $\begin{array}{c}-0.104 * * * \\
(-2.95)\end{array}$ & $\begin{array}{c}-0.119 * * * \\
(-3.32)\end{array}$ & $\begin{array}{c}-0.100 * * * \\
(-2.79)\end{array}$ & $\begin{array}{c}-0.081 * * \\
(-2.08)\end{array}$ \\
\hline Distress $_{\mathrm{t}-1}$ & & $\begin{array}{c}-0.383 * * * \\
(-4.39)\end{array}$ & $\begin{array}{c}-0.425 * * * \\
(-4.73)\end{array}$ & $\begin{array}{c}-0.419 * * * \\
(-4.65)\end{array}$ & $\begin{array}{c}-0.614 * * * \\
(-4.11)\end{array}$ \\
\hline Investment $_{\mathrm{t}-1}$ & & $\begin{array}{c}-0.188^{* *} \\
(-2.45)\end{array}$ & $\begin{array}{c}-0.241 * * * \\
(-3.07)\end{array}$ & $\begin{array}{c}-0.245 * * * \\
(-3.09)\end{array}$ & $\begin{array}{c}-0.248 * * \\
(-2.51)\end{array}$ \\
\hline AnalystFollow $_{t-1}$ & & $\begin{array}{c}-0.135^{* * *} \\
(-6.68)\end{array}$ & $\begin{array}{c}-0.133^{* * *} \\
(-6.46)\end{array}$ & $\begin{array}{c}-0.105 * * * \\
(-4.95)\end{array}$ & $\begin{array}{l}-0.015 \\
(-0.54)\end{array}$ \\
\hline $\operatorname{Acctg}_{t-1}$ & & & & $\begin{array}{c}-0.383 * * * \\
(-7.74)\end{array}$ & $\begin{array}{c}-0.271 * * * \\
(-4.93)\end{array}$ \\
\hline $\mathrm{CEOCPA}_{\mathrm{t}-1}$ & & & & $\begin{array}{c}0.305^{* * *} \\
(3.19)\end{array}$ & $\begin{array}{c}0.310^{* * *} \\
(3.03)\end{array}$ \\
\hline $\mathrm{COO}_{\mathrm{t}-1}$ & & & & $\begin{array}{l}0.072 \\
(1.52)\end{array}$ & $\begin{array}{c}0.103^{* *} \\
(1.99)\end{array}$ \\
\hline $\mathrm{ROA}_{\mathrm{t}-1}$ & & & & & $\begin{array}{l}0.226 \\
(1.52)\end{array}$ \\
\hline $\mathrm{BM}_{\mathrm{t}-1}$ & & & & & $\begin{array}{c}-0.154 * * * \\
(-3.43)\end{array}$ \\
\hline $\operatorname{Lev}_{\mathrm{t}-1}$ & & & & & $\begin{array}{l}-0.079 \\
(-0.62)\end{array}$ \\
\hline $\operatorname{Ln}\left(\mathrm{MVE}_{\mathrm{t}-1}\right)$ & & & & & $\begin{array}{c}-0.140 * * * \\
(-7.33)\end{array}$ \\
\hline Constant & $\begin{array}{c}-0.174 * * * \\
(-4.16)\end{array}$ & $\begin{array}{c}0.174 * * \\
(2.20)\end{array}$ & $\begin{array}{c}0.188 * * \\
(2.17)\end{array}$ & $\begin{array}{c}0.300 * * * \\
(3.18)\end{array}$ & $\begin{array}{c}1.171 * * * \\
(7.62)\end{array}$ \\
\hline Observations & 7,685 & 7,810 & 7,519 & 7,519 & 6,483 \\
\hline Pseudo $\mathrm{R}^{2}$ & 0.003 & 0.009 & 0.012 & 0.019 & 0.028 \\
\hline
\end{tabular}


Table 4, continued.

Panel B: Marginal effects

\begin{tabular}{|c|c|c|c|c|c|}
\hline VARIABLES & $\begin{array}{c}(1) \\
\operatorname{Pr}(\mathrm{CPA}=1)\end{array}$ & $\begin{array}{c}(2) \\
\operatorname{Pr}(\mathrm{CPA}=1)\end{array}$ & $\begin{array}{c}(3) \\
\operatorname{Pr}(\mathrm{CPA}=1)\end{array}$ & $\begin{array}{c}(4) \\
\operatorname{Pr}(\mathrm{CPA}=1)\end{array}$ & $\begin{array}{c}(5) \\
\operatorname{Pr}(\mathrm{CPA}=1)\end{array}$ \\
\hline $\mathrm{SOX}_{\mathrm{t}}$ & $\begin{array}{c}0.038^{* * *} \\
(2.93)\end{array}$ & & $\begin{array}{c}0.032 * * \\
(2.45)\end{array}$ & $\begin{array}{c}0.033^{* *} \\
(2.50)\end{array}$ & $\begin{array}{c}0.033^{* *} \\
(2.27)\end{array}$ \\
\hline IndComplexity $_{\mathrm{t}-3, \mathrm{t}-1}$ & $\begin{array}{c}0.013 * * * \\
(3.10)\end{array}$ & & $\begin{array}{c}0.019^{* * *} \\
(2.97)\end{array}$ & $\begin{array}{c}0.019 * * * \\
(3.07)\end{array}$ & $\begin{array}{c}0.022 * * * \\
(3.15)\end{array}$ \\
\hline $\mid$ Accruals $_{\mathrm{t}-1} \mid$ & $\begin{array}{l}0.037 \\
(1.13)\end{array}$ & & $\begin{array}{l}0.055 \\
(1.51)\end{array}$ & $\begin{array}{l}0.041 \\
(1.14)\end{array}$ & $\begin{array}{l}0.044 \\
(0.97)\end{array}$ \\
\hline $\mathrm{ICW}_{\mathrm{t}-1}$ & $\begin{array}{c}0.053^{* *} \\
(2.06)\end{array}$ & & $\begin{array}{l}0.049^{*} \\
(1.88)\end{array}$ & $\begin{array}{c}0.053^{* *} \\
(2.06)\end{array}$ & $\begin{array}{l}0.038 \\
(1.46)\end{array}$ \\
\hline $\mathrm{MA}_{\mathrm{t}-1}$ & & $\begin{array}{l}-0.020 \\
(-1.62)\end{array}$ & $\begin{array}{l}-0.016 \\
(-1.24)\end{array}$ & $\begin{array}{l}-0.011 \\
(-0.90)\end{array}$ & $\begin{array}{l}0.002 \\
(0.18)\end{array}$ \\
\hline $\operatorname{IndMA}_{\mathrm{t}-1}$ & & $\begin{array}{l}0.007 \\
(1.55)\end{array}$ & $\begin{array}{l}-0.003 \\
(-0.46)\end{array}$ & $\begin{array}{l}-0.005 \\
(-0.86)\end{array}$ & $\begin{array}{l}-0.006 \\
(-0.95)\end{array}$ \\
\hline GrossMargin $_{\mathrm{t}-1}$ & & $\begin{array}{c}-0.007 * \\
(-1.71)\end{array}$ & $\begin{array}{l}-0.008^{*} \\
(-1.80)\end{array}$ & $\begin{array}{l}-0.008^{*} \\
(-1.85)\end{array}$ & $\begin{array}{c}-0.010^{* *} \\
(-2.01)\end{array}$ \\
\hline IndGrossMargin $_{\mathrm{t}-1}$ & & $\begin{array}{l}0.003 \\
(0.08)\end{array}$ & $\begin{array}{l}-0.034 \\
(-0.77)\end{array}$ & $\begin{array}{l}-0.049 \\
(-1.12)\end{array}$ & $\begin{array}{c}-0.105^{* *} \\
(-2.17)\end{array}$ \\
\hline GeoSeg $_{\mathrm{t}-1}$ & & $\begin{array}{c}-0.026 * * * \\
(-2.96)\end{array}$ & $\begin{array}{c}-0.029 * * * \\
(-3.33)\end{array}$ & $\begin{array}{c}-0.024 * * * \\
(-2.79)\end{array}$ & $\begin{array}{c}-0.020^{* *} \\
(-2.08)\end{array}$ \\
\hline Distress $_{\mathrm{t}-1}$ & & $\begin{array}{c}-0.095 * * * \\
(-4.42)\end{array}$ & $\begin{array}{c}-0.104 * * * \\
(-4.76)\end{array}$ & $\begin{array}{c}-0.102 * * * \\
(-4.68)\end{array}$ & $\begin{array}{c}-0.148^{* * *} \\
(-4.13)\end{array}$ \\
\hline Investment $_{\mathrm{t}-1}$ & & $\begin{array}{c}-0.046^{* *} \\
(-2.45)\end{array}$ & $\begin{array}{c}-0.059 * * * \\
(-3.08)\end{array}$ & $\begin{array}{c}-0.060 * * * \\
(-3.09)\end{array}$ & $\begin{array}{c}-0.060^{* *} \\
(-2.52)\end{array}$ \\
\hline AnalystFollow $_{t-1}$ & & $\begin{array}{c}-0.033 * * * \\
(-6.75)\end{array}$ & $\begin{array}{c}-0.033^{* * *} \\
(-6.53)\end{array}$ & $\begin{array}{c}-0.026 * * * \\
(-4.98)\end{array}$ & $\begin{array}{l}-0.004 \\
(-0.54)\end{array}$ \\
\hline $\operatorname{Acctg}_{t-1}$ & & & & $\begin{array}{c}-0.093 * * * \\
(-7.86)\end{array}$ & $\begin{array}{c}-0.065 * * * \\
(-4.96)\end{array}$ \\
\hline CEOCPA $_{t-1}$ & & & & $\begin{array}{c}0.074 * * * \\
(3.20)\end{array}$ & $\begin{array}{c}0.075^{* * *} \\
(3.04)\end{array}$ \\
\hline $\mathrm{COO}_{\mathrm{t}-1}$ & & & & $\begin{array}{l}0.018 \\
(1.52)\end{array}$ & $\begin{array}{c}0.025^{* *} \\
(1.99)\end{array}$ \\
\hline $\mathrm{ROA}_{\mathrm{t}-1}$ & & & & & $\begin{array}{l}0.054 \\
(1.52)\end{array}$ \\
\hline $\mathrm{BM}_{\mathrm{t}-1}$ & & & & & $\begin{array}{c}-0.037 * * * \\
(-3.44)\end{array}$ \\
\hline $\operatorname{Lev}_{t-1}$ & & & & & $\begin{array}{l}-0.019 \\
(-0.62)\end{array}$ \\
\hline $\operatorname{Ln}\left(\mathrm{MVE}_{\mathrm{t}-1}\right)$ & & & & & $\begin{array}{c}-0.034 * * * \\
(-7.45)\end{array}$ \\
\hline Observations & 7,685 & 7,810 & 7,519 & 7,519 & 6,483 \\
\hline
\end{tabular}

This table presents estimates from a logistic regression of the determinants of hiring a CFO with a CPA qualification. The dependent variable equals one if the CFO hired has a CPA and zero otherwise. Panel A presents the coefficient estimates and Panel B presents the marginal effects. See Appendix A for other variable definitions. $\mathrm{z}$-statistics in parentheses, ${ }^{* * *} \mathrm{p}<0.01,{ }^{* *} \mathrm{p}<0.05,{ }^{*} \mathrm{p}<0.1$. 
Table 5: Turnover analysis

\begin{tabular}{|c|c|c|c|c|}
\hline $\begin{array}{l}\text { GROUP } \\
\text { VARIABLES }\end{array}$ & $\begin{array}{c}(1) \\
\frac{\text { non-CPAs }}{\operatorname{Pr}(\mathrm{CFO}} \\
\left.\text { Exit }_{\mathrm{t}+\mathrm{n}+1}=1\right)\end{array}$ & $\begin{array}{c}(2) \\
\frac{\mathrm{CPAs}}{\operatorname{Pr}(\mathrm{CFO}} \\
\left.\text { Exit }_{\mathrm{t}+\mathrm{n}+1}=1\right)\end{array}$ & $\begin{array}{c}(3) \\
\frac{\text { non-CPAs }}{\operatorname{Pr}(\mathrm{CFO}} \\
\left.\text { Exit }_{\mathrm{t}+\mathrm{n}+1}=1\right)\end{array}$ & $\begin{array}{c}(4) \\
\text { CPAs } \\
\operatorname{Pr}(\mathrm{CFO} \\
\left.\text { Exit }_{\mathrm{t}+\mathrm{n}+1}=1\right)\end{array}$ \\
\hline PoorFit $_{t+n}$ & $\begin{array}{c}0.209 * * * \\
(2.97)\end{array}$ & $\begin{array}{c}0.144 * * \\
(2.06)\end{array}$ & $\begin{array}{c}0.186^{* *} \\
(2.34)\end{array}$ & $\begin{array}{c}0.168 * * \\
(2.19)\end{array}$ \\
\hline $\operatorname{Ret}_{t+n}$ & $\begin{array}{c}-0.306^{* * *} \\
(-4.34)\end{array}$ & $\begin{array}{c}-0.183 * * * \\
(-2.64)\end{array}$ & $\begin{array}{c}-0.285^{* * *} \\
(-3.93)\end{array}$ & $\begin{array}{c}-0.148^{* *} \\
(-2.13)\end{array}$ \\
\hline BoardSeat $_{t}$ & $\begin{array}{c}0.224 * * * \\
(2.87)\end{array}$ & $\begin{array}{l}0.162^{*} \\
(1.80)\end{array}$ & $\begin{array}{c}0.180^{* * *} \\
(2.20)\end{array}$ & $\begin{array}{l}0.142 \\
(1.54)\end{array}$ \\
\hline CEOTenure $_{t}$ & $\begin{array}{c}-0.018 * * * \\
(-2.69)\end{array}$ & $\begin{array}{l}-0.011^{*} \\
(-1.69)\end{array}$ & $\begin{array}{c}-0.021 * * * \\
(-3.07)\end{array}$ & $\begin{array}{c}-0.015^{* *} \\
(-2.22)\end{array}$ \\
\hline $\operatorname{Age}_{t+n}$ & $\begin{array}{c}0.016 * * * \\
(3.55)\end{array}$ & $\begin{array}{l}0.002 \\
(0.35)\end{array}$ & $\begin{array}{c}0.020 * * * \\
(4.20)\end{array}$ & $\begin{array}{l}0.007 \\
(1.44)\end{array}$ \\
\hline PriorCFO $_{t}$ & $\begin{array}{c}0.194 * * * \\
(2.97)\end{array}$ & $\begin{array}{l}0.117^{*} \\
(1.76)\end{array}$ & $\begin{array}{c}0.195 * * * \\
(2.85)\end{array}$ & $\begin{array}{l}0.093 \\
(1.34)\end{array}$ \\
\hline $\operatorname{Ln}\left(\mathrm{MVE}_{\mathrm{t}+\mathrm{n}}\right)$ & $\begin{array}{c}-0.078 * * * \\
(-4.60)\end{array}$ & $\begin{array}{c}-0.100 * * * \\
(-5.47)\end{array}$ & $\begin{array}{c}-0.123 * * * \\
(-4.96)\end{array}$ & $\begin{array}{c}-0.101^{* * * *} \\
(-3.88)\end{array}$ \\
\hline $\operatorname{Lev}_{t+n}$ & $\begin{array}{l}0.146 \\
(0.99)\end{array}$ & $\begin{array}{l}0.125 \\
(0.86)\end{array}$ & $\begin{array}{l}0.224 \\
(1.23)\end{array}$ & $\begin{array}{l}0.198 \\
(1.14)\end{array}$ \\
\hline $\mathrm{BM}_{\mathrm{t}+\mathrm{n}}$ & $\begin{array}{l}-0.053 \\
(-0.97)\end{array}$ & $\begin{array}{l}0.001 \\
(0.02)\end{array}$ & $\begin{array}{l}-0.048 \\
(-0.76)\end{array}$ & $\begin{array}{l}0.046 \\
(0.77)\end{array}$ \\
\hline $\mathrm{ROA}_{\mathrm{t}+\mathrm{n}}$ & $\begin{array}{c}-0.611 * * * \\
(-3.78)\end{array}$ & $\begin{array}{c}-0.547 * * * \\
(-3.60)\end{array}$ & $\begin{array}{c}-0.847 * * * \\
(-3.81)\end{array}$ & $\begin{array}{c}-0.844 * * * \\
(-4.01)\end{array}$ \\
\hline Constant & $\begin{array}{c}-3.405^{* * * *} \\
(-2.60)\end{array}$ & $\begin{array}{c}-3.957 * * * \\
(-2.61)\end{array}$ & $\begin{array}{l}-2.233 \\
(-1.64)\end{array}$ & $\begin{array}{c}-3.355^{* *} \\
(-2.18)\end{array}$ \\
\hline Remaining determinants controls & No & No & Yes & Yes \\
\hline CFO tenure fixed effects & Yes & Yes & Yes & Yes \\
\hline Industry fixed effects & Yes & Yes & Yes & Yes \\
\hline $\begin{array}{l}\text { Observations } \\
\text { Pseudo } \mathrm{R}^{2}\end{array}$ & $\begin{array}{c}10,127 \\
0.041\end{array}$ & $\begin{array}{c}10,372 \\
0.049\end{array}$ & $\begin{array}{c}10,127 \\
0.084\end{array}$ & $\begin{array}{c}10,372 \\
0.089\end{array}$ \\
\hline
\end{tabular}

This table presents estimates from a logistic regression of the determinants of CFO turnover. The dependent variable equals one if the CFO turns over during the following year $(t+n+1)$. See Appendix A for other variable definitions. Columns (1) and (3) present results for non-CPA CFOs; Columns (2) and (4) present results for CPA CFOs. Industry fixed effects are defined using two-digit SIC codes. Robust z-statistics in parentheses, $* * * \mathrm{p}<0.01, * * \mathrm{p}<0.05, * \mathrm{p}<0.1$. 
Table 6: Executive team expansion

\section{Panel A: Change in the existence of a COO position}

DropCPA

AddCPA

Total
DropCOO

\begin{tabular}{|c|c|}
\hline 239 & 224 \\
{$[51.6 \%]$} & {$[48.4 \%]$} \\
& \\
\hline 271 & 317 \\
{$[46.2 \%]$} & {$[53.8 \%]$} \\
\hline
\end{tabular}

511

541 $\underline{\text { Total }}$

463

[44.0\%]

589

[56.0\%]

1,052

$\chi^{2}=3.071 ; p-$ value $=0.080$

Panel B: Change in the existence of an accounting related position

DropCPA

AddCPA

$\underline{\text { Total }}$

\begin{tabular}{|c|c|}
\multicolumn{1}{|c}{ DropAcctg } & AddAcctg \\
\hline 186 & 197 \\
{$[48.6 \%]$} & {$[51.4 \%]$} \\
& \\
\hline 271 & 182 \\
{$[59.8 \%]$} & {$[40.2 \%]$} \\
\hline
\end{tabular}

$\underline{\text { Total }}$

383

836

$\chi^{2}=10.617 ; p-$ value $=0.001$

This table presents two-way contingency tables for the subsample of CFO hires for which we have data on the prior CFO employed at the firm. Panel A sorts observations based on whether firms change the operational expertise of the top management team by either adding a $\mathrm{COO}$ position (AddCOO) or dropping a COO position (DropCOO) following an increase in the accounting expertise of the CFO (AddCPA) or decrease in the accounting expertise of the CFO (DropCPA). Panel B sorts observations based on whether firms either add or drop an accounting related position on the top management team (AddAcctg or DropAcctg) when the firm increases or decreases the extent of accounting expertise of the CFO (AddCPA or DropCPA). See Appendix A for variable definitions. Each cell reports total observations that fall in that cell along with the percentage of each row total that cell comprises (shown in brackets). We also report Pearson's Chi-squared for the hypothesis that the rows and columns in each table are independent. 
Table 7: Likelihood of becoming the future CEO

\begin{tabular}{|c|c|c|}
\hline \multirow[b]{2}{*}{ VARIABLES } & \multicolumn{2}{|c|}{$\begin{array}{c}(1) \\
\operatorname{Pr}\left(\mathrm{CEO}_{\mathrm{t}, \mathrm{t}+5}=1\right)\end{array}$} \\
\hline & Coefficient & Marginal effects \\
\hline $\mathrm{CPA}$ & $\begin{array}{c}-0.254^{*} \\
(-1.79)\end{array}$ & $\begin{array}{c}-0.011^{*} \\
(-1.79)\end{array}$ \\
\hline PriorCFO & $\begin{array}{c}0.277^{*} \\
(1.86)\end{array}$ & $\begin{array}{l}0.012^{*} \\
(1.85)\end{array}$ \\
\hline $\operatorname{Age}_{t}$ & $\begin{array}{l}-0.017 \\
(-1.57)\end{array}$ & $\begin{array}{l}-0.001 \\
(-1.56)\end{array}$ \\
\hline Constant & $\begin{array}{c}-2.272 * * * \\
(-4.41)\end{array}$ & \\
\hline $\begin{array}{l}\text { Observations } \\
\text { Pseudo } \mathrm{R}^{2}\end{array}$ & & \\
\hline
\end{tabular}


Table 8: Cross-sectional variation in predictive ability of hiring model

Panel A: Including all variables from hiring model

OpChange $_{t+1}=0$

OpChange $_{t+1}=1$

Difference

RetShock $_{\mathrm{t}-1}=0$

RetShock $_{\mathrm{t}-1}=1$

Difference

$\operatorname{RetVol}_{\mathrm{t}-1}=0$

$\operatorname{RetVol}_{\mathrm{t}-1}=1$

Difference

ExtHire $=0$

ExtHire $=1$

Difference

\begin{tabular}{ccc}
$\mathbf{N}$ & Pseudo $\mathbf{R}^{2}$ & \\
\hline 4,950 & 0.031 & \\
1,506 & 0.022 & p-value $=0.030$
\end{tabular}

$4,044 \quad 0.034$

$2,105 \quad 0.026$

0.008*

$p$-value $=0.074$

$3,070 \quad 0.035$

$3,413 \quad 0.026$

0.008*

$p$-value $=0.098$

$3,854 \quad 0.038$

2,279

0.029

0.009*

p-value $=0.080$

Panel B: Excluding control variables

OpChange $_{t+1}=0$

OpChange $_{t+1}=1$

Difference

RetShock $_{\mathrm{t}-1}=0$

RetShock $_{\mathrm{t}-1}=1$

Difference

$\operatorname{RetVol}_{\mathrm{t}-1}=0$

$\operatorname{RetVol}_{\mathrm{t}-1}=1$

Difference

ExtHire $=0$

ExtHire $=1$

Difference

This table presents the Pseudo $\mathrm{R}^{2}$ from estimating Equation (1) separately on various subsamples. See Appendix A for variable definitions and Appendix $\mathrm{B}$ for a description of the procedure used to calculate the significance of the differences in the Pseudo $\mathrm{R}^{2} \mathrm{~s}$. *** $\mathrm{p}<0.01, * * \mathrm{p}<0.05, * \mathrm{p}<0.1$.

$\begin{array}{ccc}4,081 & 0.026 & \\ 2,123 & 0.017 & \text { p-value }=0.050\end{array}$

$\begin{array}{ccc}3,184 & 0.027 & \\ 4,335 & 0.019 & \\ & \mathbf{0 . 0 0 8}^{*} & \text { p-value }=0.059\end{array}$

\begin{tabular}{|c|c|c|}
\hline 3,883 & 0.030 & \\
\hline 2,300 & 0.017 & \\
\hline & $0.013 * * *$ & $p$-value $=0.009$ \\
\hline
\end{tabular}

\begin{tabular}{ccc}
$\mathbf{N}$ & Pseudo $^{2}$ & \\
\hline 5,818 & 0.021 & \\
1,663 & 0.016 & p-value $=0.075$
\end{tabular}

